\title{
Reading the Recent Monetary History of the United States, 1959-2007
}

\author{
Jesús Fernández-Villaverde, Pablo Guerrón-Quintana, and Juan F. Rubio-Ramírez
}

\begin{abstract}
In this paper the authors report the results of the estimation of a rich dynamic stochastic general equilibrium (DSGE) model of the U.S. economy with both stochastic volatility and parameter drifting in the Taylor rule. They use the results of this estimation to examine the recent monetary history of the United States and to interpret, through this lens, the sources of the rise and fall of the Great Inflation from the late 1960s to the early 1980s and of the Great Moderation of business cycle fluctuations between 1984 and 2007. Their main findings are that, while there is strong evidence of changes in monetary policy during Chairman Paul Volcker's tenure at the Federal Reserve, those changes contributed little to the Great Moderation. Instead, changes in the volatility of structural shocks account for most of it. Also, although the authors find that monetary policy was different under Volcker, they do not find much evidence of a big difference in monetary policy among the tenures of Chairmen Arthur Burns, G. William Miller, and Alan Greenspan. The difference in aggregate outcomes across these periods is attributed to the time-varying volatility of shocks. The history for inflation is more nuanced, as a more vigorous stand against it would have reduced inflation in the 1970s, but not completely eliminated it. In addition, they find that volatile shocks (especially those related to aggregate demand) were important contributors to the Great Inflation. (JEL E10, E30, C11)
\end{abstract}

Federal Reserve Board of St. Louis Review, July/August 2010, 92(4), pp. 311-38.

\section{INTRODUCTION}

$\mathbf{U}$ ncovering the rationales behind monetary policy is hard. While the instruments of policy, such as the federal funds rate or reserve requirements, are directly observable, the process that led to their choice is not. Instead, we have the documentary record of the minutes of different meetings, the memoirs of participants in the process, and the internal memos circulated within the Federal Reserve System.

Although this paper trail is valuable, it is not and cannot be a complete record of the policy process. First and foremost, documents are not a perfect photograph of reality. For example, participants at Federal Open Market Committee (FOMC) meetings do not necessarily say or vote what they really would like to say or vote, but what they think is appropriate at the moment given their objectives and their assessment of the strategic interactions among the members of the committee. (The literature on cheap talk and strategic voting is precisely based on those insights.) Also, memoirs are often incomplete or faulty and staff memos are the product of negotiations and compromises among several actors. Second, even the most com-

Jesús Fernández-Villaverde is an associate professor of economics at the University of Pennsylvania, a research associate for the National Bureau of Economic Research, a research affiliate for the Centre for Economic Policy Research, and a research associate chair for FEDEA (Fundación de Estudios de Economía Aplicada). Pablo Guerrón-Quintana is an economist at the Federal Reserve Bank of Philadelphia. Juan F. Rubio-Ramírez is an associate professor of economics at Duke University and a visiting scholar at the Federal Reserve Bank of Atlanta and FEDEA. The authors thank André Kurmann, Jim Nason, Frank Schorfheide, Tao Zha, and participants at several seminars for useful comments and Béla Személy for invaluable research assistance. The authors also thank the National Science Foundation for financial support.

(C) 2010, The Federal Reserve Bank of St. Louis. The views expressed in this article are those of the author(s) and do not necessarily reflect the views of the Federal Reserve System, the Board of Governors, or the regional Federal Reserve Banks. Articles may be reprinted, reproduced, published, distributed, displayed, and transmitted in their entirety if copyright notice, author name(s), and full citation are included. Abstracts, synopses, and other derivative works may be made only with prior written permission of the Federal Reserve Bank of St. Louis. 
plete documentary evidence cannot capture the full richness of a policy decision process in a modern society. Even if it could, it would probably be impossible for any economist or historian to digest the whole archival record. ${ }^{1}$ Third, even if we could forget for a minute about the limitations of the documents, we would face the fact that actual decisions tell us only about what was done, but say little about what would have been done in other circumstances. And while the absence of an explicit counterfactual may be a minor problem for historians, it is a deep flaw for economists who are interested in evaluating policy rules and making recommendations regarding the response to future events that may be very different from past experiences.

Therefore, in this paper we investigate the history of monetary policy in the United States from 1959 to 2007 from a different perspective. We build and estimate a rich dynamic stochastic general equilibrium (DSGE) model of the U.S. economy with both stochastic volatility and parameter drifting in the Taylor rule that determines monetary policy. Then, we use the results of our estimation to examine, through the lens of the model, the recent monetary policy history of the United States. Our attention is focused primarily on understanding two fundamental observations: (i) the rise and fall of the Great Inflation from the late 1960s to the early 1980s, the only significant peacetime inflation in U.S. history, and (ii) the Great Moderation of business cycle fluctuations that the U.S. economy experienced between 1984 and 2007, as documented by Kim and Nelson (1998), McConnell and PérezQuirós (2000), and Stock and Watson (2003).

All the different elements in our exercise are necessary. We need a DSGE model because we are interested in counterfactuals. Thus, we require

1 For instance, Allan Meltzer (2010), in his monumental A History of the Federal Reserve, uses the summaries of the minutes of FOMC meetings compiled by nine research assistants (volume 2, book 1 , page X). This shows how even a several-decades-long commitment to getting acquainted with the archives is not enough to process all the relevant information. Instead, it is necessary to rely on summaries, with all the potential biases and distortions that they might bring. This is, of course, not a criticism of Meltzer: He just proceeded, as many other great historians do, by standing on the shoulders of others. Otherwise, modern archival research would be plainly impossible. a model that is structural in the sense of Hurwicz (1962)—that is, invariant to interventions such as the ones that we consider. We need a model with stochastic volatility because, otherwise, any changes in the variance of aggregate variables would be interpreted as the consequence of variations in monetary policy. The evidence in Sims and Zha (2006), Fernández-Villaverde and RubioRamírez (2007), and Justiniano and Primiceri (2008) points out that these changes in volatility are first-order considerations when we explore the data. We need a model with parameter drifting in the monetary policy rule because we want to introduce changes in policy that obey a fully specified probability distribution, and not a onceand-for-all change around 1979-80, as is often postulated in the literature (for example, in Clarida, Galí, and Gertler, 2000, and Lubick and Schorfheide, 2004).

In addition to using our estimation to interpret the recent monetary policy history of the United States, we follow Sims and Zha's (2006) call to connect estimated changes to historical events. (We are also inspired by Cogley and Sargent, 2002 and 2005.) In particular, we discuss how our estimation results relate to both the observations about the economy-for instance, how our model interprets the effects of oil shocksand the written record.

Our main findings are that, although there is strong evidence of changes in monetary policy during Chairman Paul Volcker's tenure at the Fed, those changes contributed little to the Great Moderation. Instead, changes in the volatility of structural shocks account for most of it. Also, although we find that monetary policy was different under Volcker, we do not find much evidence of a difference in monetary policy among the tenures of Chairmen Arthur Burns, G. William Miller, and Alan Greenspan. The reduction in the volatility of aggregate variables after 1984 is attributed to the time-varying volatility of shocks. The history for inflation is more subtle. According to our estimated model, a more aggressive stance of monetary policy would have reduced inflation in the 1970s, but not completely eliminated it. In addition, we find that volatile shocks (especially 
those related to aggregate demand) were important contributors to the Great Inflation.

Most of the material in this paper is based on a much more extensive and detailed work by Fernández-Villaverde, Guerrón-Quintana, and Rubio-Ramírez (2010), in which we (i) present the DSGE model in all of its detail, (ii) characterize the decision rules of the agents, (iii) build the likelihood function, and (iv) estimate the model. Here, we concentrate instead on understanding recent U.S. monetary history through the lens of our theory.

\section{A DSGE MODEL OF THE U.S. ECONOMY WITH STOCHASTIC VOLATILITY AND PARAMETER DRIFTING}

As we argued in the introduction, we need a structural equilibrium model of the economy to evaluate the importance of each of the different mechanisms behind the evolution of inflation and aggregate volatility in the United States over the past several decades. However, while the previous statement is transparent, it is much less clear how to decide which particular elements of the model to include. On the one hand, we want a model that is sufficiently detailed to account for the dynamics of the data reasonably well. But this goal conflicts with the objective of having a parsimonious and soundly microfounded description of the aggregate economy.

Given our investigation, a default choice for a model is a standard DSGE economy with nominal rigidities, such as the ones in Christiano, Eichenbaum, and Evans (2005) or Smets and Wouters (2003). This class of models is currently being used to inform policy in many central banks and is a framework that has proven to be successful at capturing the dynamics of the data. However, we do not limit ourselves to a standard DSGE model. Instead, we extend it in what we think are important and promising directions by incorporating stochastic volatility into the structural shocks and parameter drifting in the Taylor rule that governs monetary policy.
Unfortunately, for our purposes, the model has two weak points that we must acknowledge before proceeding further: money and Calvo pricing. Most DSGE models introduce a demand for money through money in the utility function (MIA) or cash in advance (CIA). By doing so, we endow money with a special function without sound justification. This hides inconsistencies that are difficult to reconcile with standard economic theory (Wallace, 2001). Moreover, the relation between structures wherein money is essential and the reduced forms embodied by MIA or CIA is not clear. This means that we do not know whether that relation is invariant to changes in monetary policy or to the stochastic properties of the shocks that hit the economy, such as the ones we study. This is nothing more than the Lucas critique dressed in a different way.

The second weakness of our DSGE model is the use of Calvo pricing. Probably the best way to think about Calvo pricing is as a convenient reduced form of a more-complicated pricing mechanism that is easier to handle, thanks to its memoryless properties. However, if we are entertaining the idea that monetary policy or the volatility of shocks has changed over time, it is exceedingly difficult to believe that the parameters that control Calvo pricing have been invariant over the same period (see the empirical evidence that supports this argument in Fernández-Villaverde and RubioRamírez, 2008).

However, getting around these two limitations seems, at the moment, infeasible. Microfounded models of money are either too difficult to work with (Kiyotaki and Wright, 1989) or rest in assumptions nearly as implausible as MIA (Lagos and Wright, 2005) or that the data find too stringent (Aruoba and Schorfheide, forthcoming). Statedependent models of pricing are too cumbersome computationally for estimation (Dotsey, King, and Wolman, 1999).

So, with a certain reluctance, we use a mainstream DSGE model with households; firms (a labor packer, a final-good producer, and a continuum of intermediate-good producers); a monetary authority, the Federal Reserve, which implements monetary policy through open market operations following a Taylor rule; and nominal rigidities in the form of Calvo pricing with partial indexation. 


\subsection{Households}

We begin our discussion of the model with households. We work with a continuum of them, indexed by $j$. Households are different because each supplies a specific type of labor in the market: Some households are carpenters and some households are economists. If, in addition, each household has some market power over its own wage and stands ready to supply any amount of labor at posted prices, it is relatively easy to introduce nominal rigidities in wages. Some households are able to change their wages and some are not, and the relative demand for each type of labor adjusts to compensate for these differences in input prices.

At the same time, we do not want a complicated model with heterogeneous agents that is daunting to compute. We resort to two tricks to get around that problem. First, we have a utility function that is separable among consumption, $c_{j t}$, real money balances, $m_{j t} / p_{t}$, and hours worked, $l_{j t}$. Second, we have complete markets in Arrow securities. Complete markets allow us to equate the marginal utilities of consumption across all households in all states of nature. And, since by separability this marginal utility depends only on consumption, all households will consume the same amount of the final good. The result makes aggregation trivial. Of course, it also has the unpleasant feature that those households that do not update their wages will work different numbers of hours than those that do. If, for example, we have an increase in the average wage, those households stuck with the old, lower wages will work longer hours and have lower total utility. This is the price we need to pay for tractability.

Given our previous choice of a separable utility function and our desire to have a balanced growth path for the economy (which requires a marginal rate of substitution between labor and consumption that is linear in consumption), we postulate a utility function of the form

$$
\mathbb{E}_{0} \sum_{t=0}^{\infty} \beta^{t} d_{t}\left\{\begin{array}{l}
\log \left(c_{j t}-h c_{j t-1}\right) \\
+v \log \left(\frac{m_{j t}}{p_{t}}\right)-\varphi_{t} \psi \frac{l_{j t}^{1+\vartheta}}{1+\vartheta}
\end{array}\right\}
$$

where $\mathbb{E}_{0}$ is the conditional expectation operator, $\beta$ is the discount factor for one quarter (the time period for our model), $h$ controls habit persistence, and $\vartheta$ is the inverse of the Frisch labor supply elasticity. In addition, we introduce two shifters to preferences, common to all households: The first is a shifter to intertemporal preference, $d_{t}$, that makes utility today more or less desirable. This is a simple device to capture shocks to aggregate demand. A prototypical example could be increases in aggregate demand caused by fiscal policy, an aspect of reality ignored in our model. Another possibility is to think about $d_{t}$ as the consequence of demographic shocks that propagate over time. The second is a shifter to labor supply, $\varphi_{t}$. As emphasized by Hall (1997), this shock is crucial for capturing the fluctuation of hours in the data.

A simple way to parameterize the evolution of the two shifters is to assume AR(1) processes:

$$
\log d_{t}=\rho_{d} \log d_{t-1}+\sigma_{d t} \varepsilon_{d t},
$$

where $\varepsilon_{d t} \sim \mathcal{N}(0,1)$, and

$$
\log \varphi_{t}=\rho_{\varphi} \log \varphi_{t-1}+\sigma_{\varphi t} \varepsilon_{\varphi t},
$$

where $\varepsilon_{\varphi t} \sim \mathcal{N}(0,1)$. The most interesting feature of these processes is that the standard deviations (SDs), $\sigma_{d t}$ and $\sigma_{\varphi t}$, of the innovations, $\varepsilon_{d t}$ and $\varepsilon_{\varphi t}$, evolve over time. This is the first place where we introduce time-varying volatility in the model: Sometimes the preference shifters are highly volatile; sometimes they are less so. This changing volatility may reflect, for instance, the different regimes of fiscal policy or the consequences of demographic forces (Jaimovich and Siu, 2009).

We can specify many different processes for $\sigma_{d t}$ and $\sigma_{\varphi t}$. A simple procedure is to assume that $\sigma_{d t}$ and $\sigma_{\varphi t}$ follow a Markov chain and take a finite number of values. While this specification seems straightforward, it is actually quite involved. The distribution that it implies for $\sigma_{d t}$ and $\sigma_{\varphi t}$ is discrete and, therefore, perturbation methods (such as the ones that we use later) are ill designed to deal with it. Such conditions would force us to rely on global solution methods that are too slow for estimation. 
Instead, we can postulate simple AR(1) processes in logs (to ensure the positivity of the SDs):

$$
\log \sigma_{d t}=\left(1-\rho_{\sigma_{d}}\right) \log \sigma_{d}+\rho_{\sigma_{d}} \log \sigma_{d t-1}+\eta_{d} u_{d t},
$$

where $u_{d t} \sim \mathcal{N}(0,1)$, and

$$
\log \sigma_{\varphi t}=\left(1-\rho_{\sigma_{\varphi}}\right) \log \sigma_{\varphi}+\rho_{\sigma_{\varphi}} \log \sigma_{\varphi t-1}+\eta_{\varphi} u_{\varphi t},
$$

where $u_{\varphi t} \sim \mathcal{N}(0,1)$. This specification is both parsimonious (with only four new parameters, $\rho_{\sigma_{d}}, \rho_{\sigma_{\varphi}}, \eta_{d}$, and $\eta_{\varphi}$ ) and rather flexible. Because of these advantages, we impose the same specification for the other three time-varying SDs in the model that appear below (the ones affecting an investment-specific technological shock, a neutral technology shock, and a monetary policy shock). Hereafter, agents perfectly observe the structural shocks and the level and innovation to the SDs and have rational expectations about their stochastic properties.

Households keep a rich portfolio: They own (physical) capital, $k_{j t}$; nominal government bonds, $b_{j t}$, that pay a gross return $R_{t-1}$; Arrow securities, $a_{j t+1}$, which pay one unit of consumption in event $\omega_{j t+1, t}$ traded at time $t$ at unitary price $q_{j t+1, t}$; and cash.

The evolution of capital deserves some description. Given a depreciation rate $\delta$, the amount of capital owned by household $j$ at the end of period $t$ is

$$
k_{j t}=(1-\delta) k_{j t-1}+\mu_{t}\left(1-V\left[\frac{x_{j t}}{x_{j t-1}}\right]\right) x_{j t} .
$$

Investment, $x_{j t}$, is multiplied by a term that depends on a quadratic adjustment cost function,

$$
V\left[\frac{x_{t}}{x_{t-1}}\right]=\frac{\kappa}{2}\left(\frac{x_{t}}{x_{t-1}}-\Lambda_{x}\right)^{2},
$$

written in deviations with respect to the balanced growth rate of investment, $\Lambda_{x}$, with adjustment parameter $\kappa$ and an investment-specific technology level $\mu_{t}$. This technology level evolves as a random walk in logs:

$$
\log \mu_{t}=\Lambda_{\mu}+\log \mu_{t-1}+\sigma_{\mu t} \varepsilon_{\mu t},
$$

where $\varepsilon_{\mu t} \sim \mathcal{N}(0,1)$ with drift $\Lambda_{\mu}$ and innovation $\varepsilon_{\mu t}$, whose SD $\sigma_{\mu t}$ evolves according to our favorite autoregressive process:

$$
\log \sigma_{\mu t}=\left(1-\rho_{\sigma_{\mu}}\right) \log \sigma_{\mu}+\rho_{\sigma_{\mu}} \log \sigma_{\mu t-1}+\eta_{\mu} u_{\mu t},
$$

where $u_{\mu t} \sim \mathcal{N}(0,1)$.

We introduce this shock convinced by the evidence in Greenwood, Herkowitz, and Krusell (1997) that this is a key mechanism to understanding aggregate fluctuations in the United States over the past 50 years.

Thus, the $j$ th household's budget constraint is

$$
\begin{aligned}
& c_{j t}+x_{j t}+\frac{m_{j t}}{p_{t}}+\frac{b_{j t+1}}{p_{t}}+\int q_{j t+1, t} a_{j t+1} d \omega_{j t+1, t} \\
& =w_{j t} l_{j t}+\left(r_{t} u_{j t}-\mu_{t}^{-1} \Phi\left[u_{j t}\right]\right) k_{j t-1} \\
& +\frac{m_{j t-1}}{p_{t}}+R_{t-1} \frac{b_{j t}}{p_{t}}+a_{j t}+T_{t}+F_{t},
\end{aligned}
$$

where $w_{j t}$ is the real wage, $r_{t}$ is the real rental price of capital, $u_{j t}>0$ is the rate of use of capital, $\mu_{t}^{-1} \Phi\left[u_{j t}\right]$ is the cost of using capital at rate $u_{j t}$ in terms of the final good, $\mu_{t}$ is an investment-specific technology level, $T_{t}$ is a lump-sum transfer, and $F_{t}$ is the profits of the firms in the economy. We postulate a simple quadratic form for $\Phi[\cdot]$,

$$
\Phi[u]=\Phi_{1}(u-1)+\frac{\Phi_{2}}{2}(u-1)^{2},
$$

and normalize $u$, the utilization rate in the balanced growth path of the economy, to 1 . This imposes the restriction that the parameter $\Phi_{1}$ must satisfy $\Phi_{1}=\Phi^{\prime}[1]=\tilde{r}$, where $\tilde{r}$ is the balanced growth path rental price of capital (rescaled by technological progress, as we explain later).

Of all the choice variables of the households, the only one that requires special attention is hours. As we explained previously, each household $j$ supplies its own specific type of labor. This labor is aggregated by a labor packer into homogeneous labor, $I_{t}^{d}$, according to a constant elasticity of substitution technology,

$$
l_{t}^{d}=\left(\int_{0}^{1} l_{j t}^{\frac{\eta-1}{\eta}} d j\right)^{\frac{\eta}{\eta-1}}
$$


The labor packer is perfectly competitive and takes all the individual wages, $w_{j t}$, and the wage $w_{t}$ for $l_{t}^{d}$ as given.

The household decides, given the demand function for its type of labor generated by the labor packer,

$$
l_{j t}=\left(\frac{w_{j t}}{w_{t}}\right)^{-\eta} l_{t}^{d} \quad \forall j,
$$

which wage maximizes its utility and stands ready to supply any amount of labor at that wage. However, when it chooses the wage, the household is subject to a nominal rigidity: a Calvo pricing mechanism with partial indexation. At the start of every quarter, a fraction $1-\theta_{w}$ of households are randomly selected and allowed to reoptimize their wages. All other households can only index their wages to past inflation with an indexation parameter $\chi_{w} \in[0,1]$.

\subsection{Firms}

In addition to the labor packer, we have two other types of firms in this economy. The first, the final-good producer, is a perfectly competitive firm that aggregates a continuum of intermediate goods with the technology:

(2) $y_{t}^{d}=\left(\int_{0}^{1} y_{i t}^{\frac{\varepsilon-1}{\varepsilon}} d i\right)^{\frac{\varepsilon}{\varepsilon-1}}$.

This firm takes as given all intermediate-good prices, $p_{t i}$, and the final-good price, $p_{t}$, and generates a demand function for each intermediate good:

(3) $y_{i t}=\left(\frac{p_{i t}}{p_{t}}\right)^{-\varepsilon} y_{t}^{d} \quad \forall i$.

Second, we have the intermediate-good producers, each of which has access to a CobbDouglas production function,

$$
y_{i t}=A_{t} k_{i t-1}^{\alpha}\left(l_{i t}^{d}\right)^{1-\alpha},
$$

where $k_{i t-1}$ is the capital, $l_{i t}^{d}$ is the packed labor rented by the firm, and $A_{t}$ (our fourth structural shock) is the neutral productivity level, which evolves as a random walk in logs:

$$
\log A_{t}=\Lambda_{A}+\log A_{t-1}+\sigma_{A t} \varepsilon_{A t},
$$

where $\varepsilon_{A t} \sim \mathcal{N}(0,1)$ with drift $\Lambda_{A}$ and innovation $\varepsilon_{A t}$. We keep the same specification for the SD of this innovation as we did for all previous volatilities:

$$
\log \sigma_{A t}=\left(1-\rho_{\sigma_{A}}\right) \log \sigma_{A}+\rho_{\sigma_{A}} \log \sigma_{A t-1}+\eta_{A} u_{A t},
$$

where $u_{A t} \sim \mathcal{N}(0,1)$.

The quantity sold of the good is determined by the demand function (equation (3)). Given equation (3), the intermediate-good producers set prices to maximize profits. As was the case for households, intermediate-good producers are subject to a nominal rigidity in the form of Calvo pricing. In each quarter, a proportion of them, $1-\theta_{p}$, can reoptimize their prices. The remaining fraction $\theta_{p}$ indexes their prices by a fraction $\chi \in[0,1]$ of past inflation.

\subsection{The Policy Rule of the Federal Reserve}

In our model, the Federal Reserve implements monetary policy through open market operations (that generate lump-sum transfers, $T_{t}$, to maintain a balanced budget). In doing so, the Fed follows a modified Taylor rule that targets the ratio of nominal gross return, $R_{t}$, of government bonds over the balanced growth path gross return, $R$ :

$$
\frac{R_{t}}{R}=\left(\frac{R_{t-1}}{R}\right)^{\gamma_{R}}\left(\left(\frac{\Pi_{t}}{\Pi}\right)^{\gamma_{\Pi, t}}\left(\frac{\frac{y_{t}}{y_{t-1}}}{\exp \left(\Lambda_{y}\right)}\right)^{\gamma_{y, t}}\right)^{1-\gamma_{R}} \xi_{t} .
$$

This rule depends on (i) the past $R_{t-1}$, which smooths changes over time; (ii) the "inflation gap," $\Pi_{t} / \Pi$, where $\Pi$ is the balanced growth path of inflation ${ }^{2}$; (iii) the "growth gap," which is the ratio

\footnotetext{
2 Here we are being careful with our words: $\Pi$ is inflation in the balanced growth path, not the target of inflation in the stochastic steady state. As we will see later, we solve the model using a secondorder approximation. The second-order terms move the mean of the ergodic distribution of inflation, which corresponds in our view to the usual view of the inflation target, away from the balanced growth path level. We could have expressed the policy rule in terms of this mean of the ergodic distribution, but it would amount to solving a complicated fixed-point problem (for every inflation level, we would need to solve the model and check that indeed this is the mean of the ergodic distribution), which is too complicated a task for the potential benefits we can derive from it.
} 
between the growth rate of the economy, $y_{t} / y_{t-1}$, and $\Lambda_{y}$, the balanced path gross growth rate of $y_{t}$, dictated by the drifts of neutral and investmentspecific technological change; and (iv) a monetary policy shock, $\xi_{t}=\exp ^{\sigma_{m, t} \varepsilon_{m t}}$, with an innovation $\varepsilon_{m t} \sim \mathcal{N}(0,1)$ and SD of the innovation, $\sigma_{m, t}$, that evolves as

$$
\log \sigma_{m t}=\left(1-\rho_{\sigma_{m}}\right) \log \sigma_{m}+\rho_{\sigma_{m}} \log \sigma_{m t-1}+\eta_{m} u_{m, t} .
$$

Note that, since we are dealing with a general equilibrium model, once the Fed has chosen a value of $\Pi, R$ is not a free target, as it is determined by technology, preferences, and $\Pi$.

We introduce monetary policy changes through a parameter drift over the responses of $R_{t}$ to inflation, $\gamma_{\Pi, t}$, and growth gaps, $\gamma_{\mathrm{y}, t}$ :

$$
\log \gamma_{\Pi t}=\left(1-\rho_{\gamma_{\Pi}}\right) \log \gamma_{\Pi}+\rho_{\gamma_{\Pi}} \log \gamma_{\Pi t-1}+\eta_{\pi} \varepsilon_{\pi t},
$$

where $\varepsilon_{\pi t} \sim \mathcal{N}(0,1)$ and

$$
\log \gamma_{y t}=\left(1-\rho_{\gamma_{y}}\right) \log \gamma_{y}+\rho_{\gamma_{y}} \log \gamma_{y t-1}+\eta_{y} \varepsilon_{y t},
$$

where $\varepsilon_{\text {yt }} \sim \mathcal{N}(0,1)$.

In preliminary estimations, we discovered that, while other parameters such as $\gamma_{R}$ could also be changing, the likelihood function of the model did not react much to that possibility and, thus, we eliminated those channels.

Our parameter-drifting specification tries to capture mainly two different phenomena. First, changes in the composition of the voting members of the FOMC (through changes in governors and in the rotating votes of presidents of regional Reserve Banks) may affect how strongly the FOMC responds to inflation and output growth because of variations in the political-economic equilibrium in the committee. ${ }^{3}$ Similarly, changes in staff may have effects as long as their views have an impact on the voting members through briefings and other, less-structured interactions. This may have

\footnotetext{
3 According to Walter Heller, President Kennedy clearly stated, "About the only power I have over the Federal Reserve is the power of appointment, and I want to use it" (cited by Bremner, 2004, p. 160). The slowly changing composition of the Board of Governors may lead to situations, such as the one in February 1986 (discussed later in the text), when Volcker was outvoted by Ronald Reagan's appointees on the Board.
}

been particularly true in the late 1960s, when a majority of staff economists embraced Keynesian policies and the MIT-Penn-Federal Reserve System (MPS) model was built. ${ }^{4}$ The second phenomenon is the observation that, even if we keep constant the members of the FOMC, their reading of the priorities and capabilities of monetary policy may evolve (or be more or less influenced by the general political climate of the nation). We argue below that this is a good description of Martin, who changed his beliefs about how strongly the Fed could fight inflation in the late 1960s, or of Greenspan's growing conviction in the mid-1990s that the long-run growth rate of the U.S. economy had risen.

While this second channel seems well described by a continuous drift in the parameters (beliefs plausibly evolving slowly), changes in the voting members, in particular the Chairman, might potentially be better understood as discrete jumps in $\gamma_{\Pi, t}$ and $\gamma_{\mathrm{y}, t}$. In fact, our smoothed path of $\gamma_{\Pi, t}$, which we estimate from the data, gives some support to this view. But in addition to our pragmatic consideration that computing models with discrete jumps is hard, we argue in Section 6 that, historically, changes have occurred more slowly and even new Chairmen have required some time before taking a decisive lead on the FOMC (Goodfriend and King, 2005).

In Section 7, we discuss other objections to our form of parameter drifting-in particular the objection to the assumption that agents observe the changes in parameters without problem, its exogeneity, or its avoidance of open economy considerations.

\subsection{Aggregation and Equilibrium}

The model is closed by finding an expression for aggregate demand,

$$
y_{t}^{d}=c_{t}+x_{t}+\mu_{t}^{-1} \Phi\left[u_{t}\right] k_{t-1},
$$

and another for aggregate supply,

4 The MPS model is the high-water mark of traditional Keynesian macroeconometric models in the Cowles tradition. The MPS model was used operationally by staff economists at the Fed from the early 1970s to the mid-1990s (see Brayton et al., 1997). 


$$
y_{t}^{s}=\frac{1}{V_{t}^{p}} A_{t}\left(u_{t} k_{t-1}\right)^{\alpha}\left(l_{t}^{d}\right)^{1-\alpha},
$$

where

$$
l_{t}^{d}=\frac{1}{V_{t}^{W}} \int_{0}^{1} l_{j t} d j
$$

is demanded labor,

$$
v_{t}^{W}=\int_{0}^{1}\left(\frac{w_{j t}}{w_{t}}\right)^{-\eta} d j
$$

is the aggregate loss of labor input induced by wage dispersion, and

$$
v_{t}^{p}=\int_{0}^{1}\left(\frac{p_{i t}}{p_{t}}\right)^{-\varepsilon} d i
$$

is the aggregate loss of efficiency induced by price dispersion of the intermediate goods. By market clearing, $y_{t}=y_{t}^{d}=y_{t}^{s}$.

The definition of "equilibrium" for this model is rather standard: It is just the path of aggregate quantities and prices that maximize the problems of households and firms, the government follows its Taylor rule, and markets clear. But while the definition of equilibrium is straightforward, its computation is not.

\section{SOLUTION AND LIKELIHOOD EVALUATION}

The solution of our model is challenging. We have 19 state variables, 5 innovations to the structural shocks $\left(\varepsilon_{d t}, \varepsilon_{\varphi t}, \varepsilon_{A t}, \varepsilon_{\mu t}, \varepsilon_{m t}\right), 2$ innovations to the parameter drifts $\left(\varepsilon_{\pi t}, \varepsilon_{y t}\right)$, and 5 innovations to the volatility shocks $\left(u_{d t}, u_{\varphi t}, u_{\mu t}, u_{A t}, u_{m t}\right)$, for a total of 31 variables that we must consider.

A vector of 19 states makes it impossible to use value-function iteration or projection methods (finite elements or Chebyshev polynomials). The curse of dimensionality is too acute even for the most powerful of existing computers. Standard linearization techniques do not work either: Stochastic volatility is inherently a nonlinear process. If we solved the model by linearization, all terms associated with stochastic volatility would disappear because of certainty equivalence and our investigation would be essentially worthless.

Nearly by default, then, using perturbation to obtain a higher-order approximation to the equilibrium dynamics of our model is the only option. A second-order approximation includes terms that depend on the level of volatility. Thus, these terms capture the responses of agents (households and firms) to changes in volatility. At the same time, a second-order approximation can be found sufficiently fast, which is of the utmost importance since we want to estimate the model and that forces us to solve it repeatedly for many different parameter values. Thus, a second-order approximation is an interesting compromise between accuracy and speed.

The idea of perturbation is simple. Instead of the exact decision rule of the agents in the model, we use a second-order Taylor expansion to the rule around the steady state. That Taylor expansion depends on the state variables and on the innovations. However, we do not know the coefficients multiplying each term of the expansion. Fortunately, we can find them by an application of the implicit function theorem as follows (see also Judd, 1998, and Schmitt-Grohé and Uribe, 2006).

First, we write all the equations describing the equilibrium of the model (optimality conditions for the agents, budget and resource constraints, the Taylor rule, and the laws of motion for the different stochastic processes). Second, we rescale all the variables to remove the balanced growth path induced by the presence of the drifts in the evolution of neutral and investment-specific technology. Third, we find the steady state implied by the rescaled variables. Fourth, we linearize the equilibrium conditions around the steady state found in the previous step. Then, we solve for the unknown coefficients in this linearization, which happen to be, by the implicit function theorem, the coefficients of the first-order terms of the decision rules in the rescaled variables that we are looking for (which can be easily rearranged to deliver the decision rules in the original variables). The next step is to take a second-order approximation of the equilibrium conditions, plugging in the terms found before, and solve for the coef- 
ficients of the second-order terms of the decision rules.

While we could keep iterating in this procedure for as long as we want, Aruoba, FernándezVillaverde, and Rubio-Ramírez (2006) show that, for the basic stochastic neoclassical growth model (the backbone of our model) calibrated to the U.S. data, a second-order approximation delivers excellent accuracy at great computational speed. In our actual computation, we undertake the symbolic derivatives of the equilibrium conditions using Mathematica 6.0. The code generates all of the relevant expressions and exports them automatically into Fortran files. Then, Fortran sends particular parameter values in each step of the estimation, evaluates those expressions, and determines the terms of the Taylor expansions that we need.

Once we have the approximated solution to the model, given some parameter values, we use it to build a state-space representation of the dynamics of states and observables. This representation is, as we argued before, nonlinear and hence standard techniques such as the Kalman filter cannot be applied to evaluate the associated likelihood function. Instead, we resort to a simulation method known as the particle filter, as applied to DSGE models by Fernández-Villaverde and Rubio-Ramírez (2007). The particle filter generates a simulation of different states of the model and evaluates the probability of the innovations that make these simulated states explain the observables. These probabilities are also called weights. A simple application of a law of large numbers tells us that the mean of the weights is an evaluation of the likelihood. The secret of the success of the procedure is that, instead of performing the simulation over the whole sample, we perform it only period by period, resampling from the set of simulated state variables according to the weights we just found. This sequential structure, which makes the particle filter a case of a more general class of algorithms called sequential Monte Carlo methods, ensures that the simulation of the state variables remains centered on the true but unknown value of the state variables. This dramatically limits the numerical variance of the procedure.
Now that we have an evaluation of the likelihood of the model given observables, we only need to search over different parameter values according to our favorite estimation algorithm. This can be done in two ways. One is with a regular maximum likelihood algorithm: We look for a global maximum of the likelihood. This procedure is complicated by the fact that the evaluation of the likelihood function that we obtain from the particle filter is nondifferentiable with respect to the parameters because of the inherent discreteness of the resampling step. An easier alternative, and one that allows the introduction of presample information, is to follow a Bayesian approach. In this route, we specify a prior over the parameters, multiply the likelihood by it, and sample from the resulting posterior by means of a random-walk Metropolis-Hastings algorithm. In this paper, we choose this second route. In our estimation, however, we do not take full advantage of presample information since we impose flat priors to facilitate the communication of the results to other researchers: The shape of our posterior distributions will be proportional to the likelihood. We must note, however, that relying on flat priors forces us to calibrate some parameters to values typically used in the literature (see FernándezVillaverde, Guerrón-Quintana, and Rubio-Ramírez, 2010 [FGR hereafter], for the values and justification of the calibrated values).

While our description of the solution and estimation method has been necessarily brief, the reader is invited to check FGR for additional details. In particular, FGR characterize the structure of the higher-order approximations, showing that many of the relevant terms are zero and exploiting this result to quickly solve for the innovations that explain the observables given some states. This result, proved for a general class of DSGE models with stochastic volatility, is bound to have wide application in all cases where stochastic volatility is an important aspect of the problem.

\section{ESTIMATION}

To estimate our model, we use five time series for the U.S. economy: (i) the relative price of 
Table 1

Posterior Distributions: Parameters of the Stochastic Processes for Volatility Shocks

\begin{tabular}{ccccc}
\multicolumn{5}{c}{ Parameter } \\
\hline $\log \sigma_{\boldsymbol{d}}$ & $\log \sigma_{\varphi}$ & $\log \sigma_{\mu}$ & $\log \sigma_{\boldsymbol{A}}$ & $\log \sigma_{\boldsymbol{m}}$ \\
\hline-1.9834 & -2.4983 & -6.0283 & -3.9013 & -6.000 \\
$(0.0726)$ & $(0.0917)$ & $(0.1278)$ & $(0.0745)$ & $(0.1471)$ \\
$\rho_{\sigma_{\boldsymbol{d}}}$ & $\rho_{\sigma_{\varphi}}$ & $\rho_{\sigma_{\mu}}$ & $\rho_{\sigma_{\boldsymbol{m}}}$ \\
\hline 0.9506 & 0.1275 & 0.7508 & 0.2411 & 0.8550 \\
$(0.0298)$ & $(0.0032)$ & $(0.035)$ & $(0.005)$ & $(0.0231)$ \\
$\eta_{\boldsymbol{d}}$ & $\eta_{\varphi}$ & $\eta_{\mu}$ & $\eta_{\boldsymbol{m}}$ \\
\hline 0.3246 & 2.8549 & 0.4716 & 0.7955 & 1.1034 \\
$(0.0083)$ & $(0.0669)$ & $(0.006)$ & $(0.013)$ & $(0.0185)$
\end{tabular}

NOTE: Numbers in parentheses indicate standard deviations.

investment goods with respect to the price of consumption goods, (ii) the federal funds rate, (iii) real per capita output growth, (iv) the consumer price index, and (v) real wages per capita. Our sample covers 1959:Q1 to 2007:Q1.

Figure 1 plots three of the five series: inflation, (per capita) output growth, and the federal funds rate-the three series most commonly discussed when commentators talk about monetary policy. By refreshing our memory about their evolution in the sample, we can frame the rest of our discussion. For ease of reading, each vertical bar corresponds to the tenure of one Fed Chairman: Martin, Burns-Miller (we merge these two because of Miller's short tenure), Volcker, Greenspan, and Bernanke.

The top panel shows the history of the Great Inflation: From the late 1960s to the mid-1980s, the U.S. experienced its only significant inflation in peace time, with peaks of around 12 to 14 percent during the 1973 and 1979 oil shocks. The middle panel shows the Great Moderation: A simple inspection of the series after 1984 reveals a much smaller amplitude of fluctuations (especially between 1993 and 2000) than before that date. The Great Inflation and the Great Moderation are the two main empirical facts to keep in mind for the rest of the paper. The bottom panel shows the federal funds rate, which follows a pattern similar to inflation: It rises in the 1970s (although less than inflation during the earlier years of the decade and more during the last years) and stays much lower in the 1990s, reaching historical minima by the end of the sample.

The point estimates we get from our posterior distribution agree with other estimates in the literature. For example, we document a fair amount of nominal rigidities in the economy. In any case, we refer the reader to FGR to avoid a lengthy discussion. Here, we report only the modes and SDs of the posterior distributions associated with the parameters governing stochastic volatility (Table 1) and policy (Table 2). In our view, those parameters are the most relevant for our reading of the recent history of monetary policy in the United States.

The main lesson from Table 1 is that the scale parameters, $\eta_{i}$, are clearly positive and bounded away from zero, confirming the presence of timevariant volatility in the data. Shocks to the volatility of the intertemporal preference shifter, $\sigma_{d}$, are the most persistent (also, the SDs are tight enough to suggest that we are not suffering from serious identification problems). The innovations to the volatility of the intratemporal labor shock, $\eta_{\varphi}$, are large in magnitude, which suggests that labor supply shocks may have played an important role during the Great Inflation by moving the marginal 
Figure 1

Time Series for Inflation, Output Growth, and the Federal Funds Rate
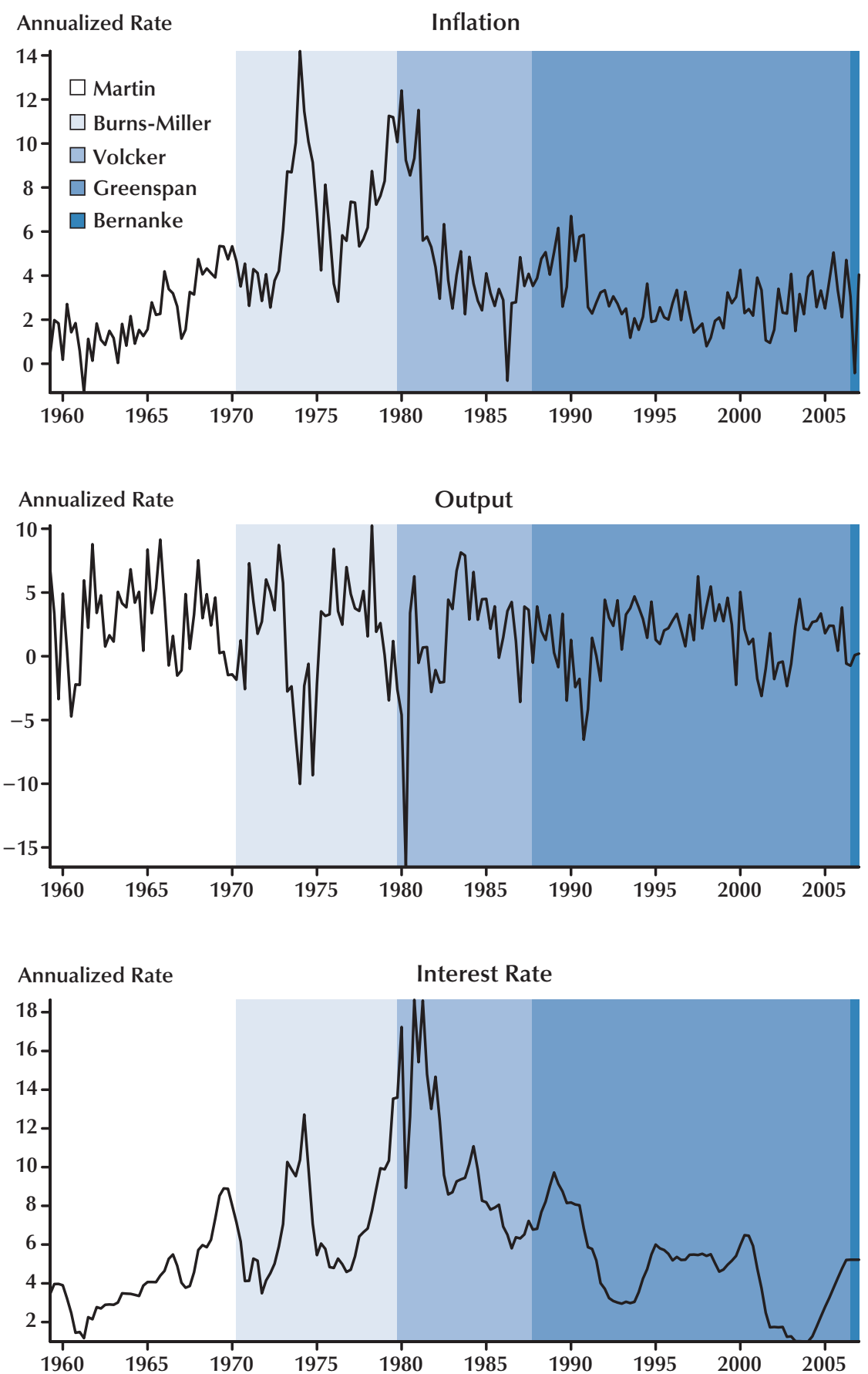
Table 2

Posterior Distribution: Policy Parameters

\begin{tabular}{ccccc}
\multicolumn{5}{c}{ Parameter } \\
\hline$\gamma_{\boldsymbol{R}}$ & $\log \gamma_{y}$ & $\Pi$ & $\log \gamma_{\Pi}$ & $\eta_{\pi}$ \\
\hline 0.7855 & -1.4034 & 1.0005 & 0.0441 & 0.1479 \\
$(0.0162)$ & $(0.0498)$ & $(0.0043)$ & $(0.0005)$ & $(0.002)$
\end{tabular}

NOTE: Numbers in parentheses indicate standard deviations.

cost of intermediate-good producers. Finally, the estimates for the volatility process governing investment-specific productivity suggest that such shocks are important in accounting for business cycles fluctuations in the United States (Fisher, 2006).

The results from Table 2 indicate that the central bank smooths interest rates $\left(\gamma_{R}>0\right)$. The parameter $\gamma_{\Pi}$ is the average magnitude of the response to inflation in the Taylor rule. Its estimated value (1.045 in levels) is just enough to guarantee determinacy in the model (Woodford, 2003). ${ }^{5}$ The size of the innovations to the drifting inflation parameter, $\eta_{\pi}$, reaffirms our view of a time-dependent response to inflation in monetary policy. The estimates for $\gamma_{y, t}$ (the response to output deviations in the Taylor rule) are not reported because preliminary attempts at estimation convinced us that $\eta_{y}$ was nil. Hence, in our next exercises, we set $\rho_{\gamma_{v}}$ and $\eta_{y}$ to zero.

\section{TWO FIGURES}

In this section, we present two figures that show us much about the evolution and effects of monetary policy: (i) the estimated smoothed path of $\gamma_{\Pi t}$ over our sample and (ii) the evolution during the same years of a measure of the real interest rate. In the next section, we map these figures into the historical record.

Figure 2, perhaps the most important figure in this paper, plots the smoothed estimate of the evolution of the response of monetary policy to

5 In this model, local determinacy depends only on the mean of $\gamma_{\Pi}$. inflation plus or minus a 2-SD interval given our point estimates of the structural parameters. The message of Figure 2 is straightforward. According to our model, at the arrival of the Kennedy administration, the response of monetary policy to inflation was around its estimated mean, slightly over $1 .{ }^{6}$ It grew more or less steadily during the 1960s, until reaching a peak at the end of 1967 and beginning of 1968. Subsequently, $\gamma_{\Pi t}$ fell so quickly that it was below 1 by 1971. For nearly all of the 1970s, $\gamma_{\Pi t}$ stayed below 1 and picked up only with the arrival of Volcker. Interestingly, the two oil shocks did not have an impact on the estimated $\gamma_{\Pi t}$. The parameter stayed high throughout the Volcker years and fell after a few quarters into Greenspan's tenure, when it returned to levels even lower than during the Burns and Miller years. The likelihood function favors an evolving monetary policy even after introducing stochastic volatility in the model. In FGR, we assess this statement more carefully with several measures of model fit, including the construction of Bayes factors and the computation of Bayesian information criteria between different specifications of the model.

The reader could argue, with some justification, that we have estimated a large DSGE model and that it is not clear what is driving the results and what variation in the data is identifying the movements in monetary policy. While a fully worked-out identification analysis is beyond the scope of this paper, as a simple reality check, we plot in Figure 3 a measure of the (short-term)

\footnotetext{
6 This number nearly coincides with the estimate of Romer and
} Romer (2002a) of the coefficient using data from the 1950s. 
Figure 2

Smoothed Path for the Taylor Rule Parameter on Inflation \pm 2 SDs

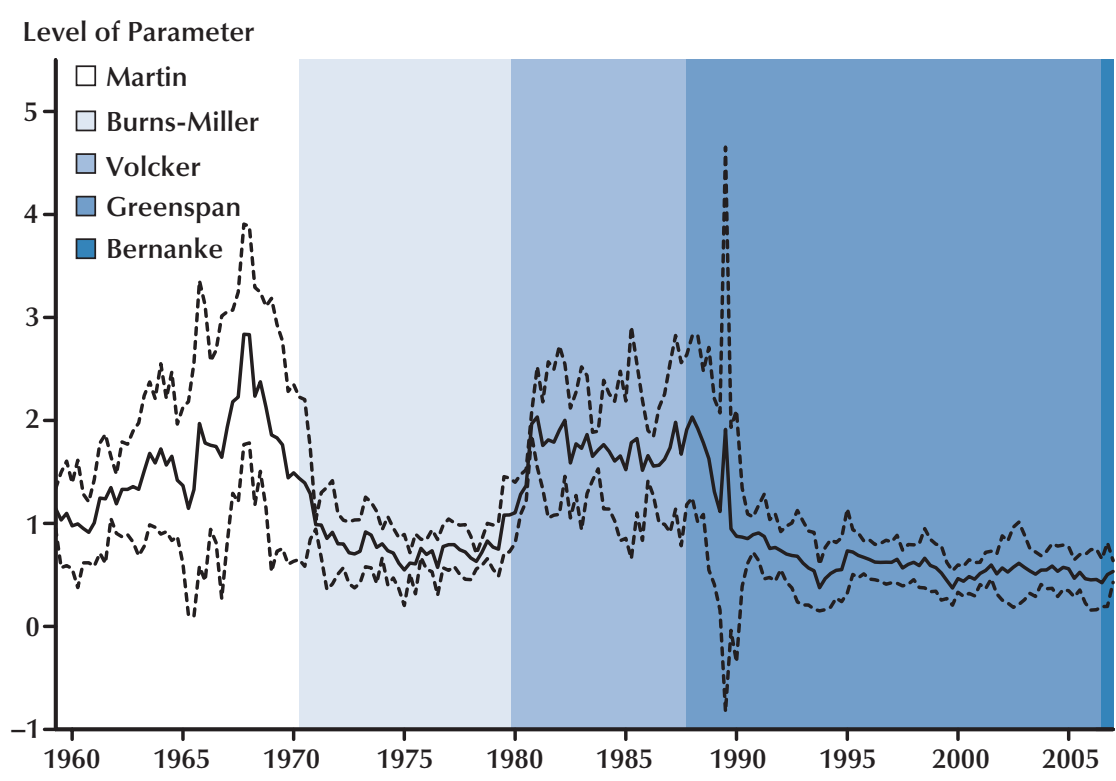

Figure 3

\section{Real Interest Rate (Federal Funds Rate Minus Inflation)}

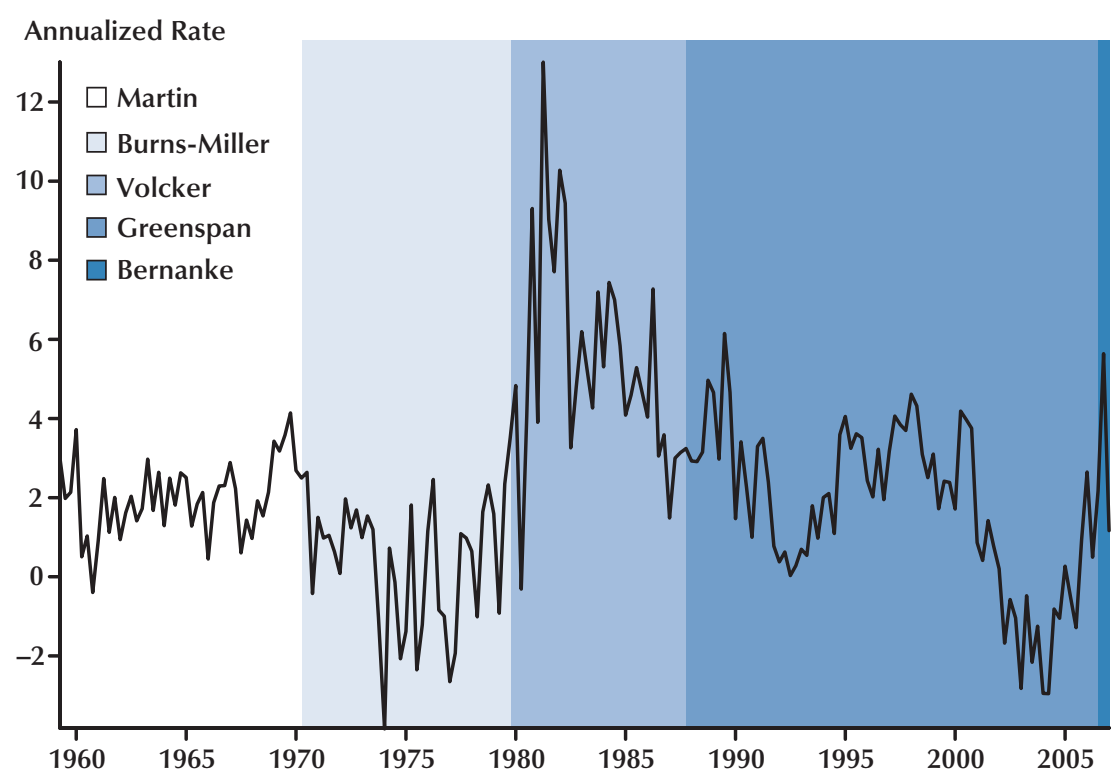


real interest rate defined as the federal funds rate minus current inflation. ${ }^{7}$

This figure shows that Martin kept the real interest rate at positive values around 2 percent during the 1960s (with a peak by the end, which corresponds with the peak of our estimated $\gamma_{\Pi t}$ ). However, during the 1970s, the real interest rate was often negative and only rarely above 2 percent, a rather conservative lower bound on the balanced growth real interest rate given our point estimates. The likelihood function can interpret those observations only as a very low $\gamma_{\Pi t}$ (remember that the Taylor principle calls for increases in the real interest rate when inflation rises; that is, nominal interest rates must grow more than inflation). Real interest rates skyrocketed with the arrival of Volcker, reaching a historic record of 13 percent by 1981:Q2. After that date, they were never even close to zero, and only in two quarters were they below 3 percent. Again, the likelihood function can interpret that observation only as a high $\gamma_{\Pi t}$. The Greenspan era is more complicated because real interest rates were not particularly low in the 1990s. However, output growth was very positive, which pushed the interest rates up in the Taylor rule. Since the federal funds rate was not as high as the policy rule would have predicted with a high $\gamma_{\Pi t}$, the smoothed estimate of the parameter is lowered. During the 2000s, real interest rates close to zero were enough, by themselves, to keep $\gamma_{\Pi t}$ low.

\section{READING MONETARY HISTORY THROUGH THE LENS OF OUR MODEL}

Now that we have our model and our estimates of the structural parameters, we smooth the structural and volatility shocks implied by the data and use them to read the recent monetary history of the United States. Somewhat conventionally, we organize our discussion around the different Chairmen of the Fed from Martin to

7 Since inflation is nearly a random walk (Stock and Watson, 2007), its current value is an excellent proxy for its expected value. In any case, our argument is fully robust to slightly different definitions of the real interest rate.
Greenspan-except for Miller, whom we group with Burns because of his short tenure.

One fundamental lesson from this exercise is that Figure 2 can successfully guide our interpretation of policy from 1959 to 2007. We document how both Martin and Volcker believed that inflation was dangerous and that the Fed had both the responsibility and the power to fight it, although growing doubts about that power overcame Martin during his last term as Chairman. Burns, on the other hand, thought the costs of inflation were lower than the cost of a recession triggered by disinflation. In any case, he was rather skeptical about the Fed's ability to successfully disinflate. Greenspan, despite his constant warnings about inflation, had in practice a much more nuanced attitude. According to our estimated model, good positive shocks to the economy gave him the privilege of skipping a daunting test of his resolve.

Because by using a DSGE model we have a complete set of structural and volatility shocks, in FGR, we complete this analysis with the construction of counterfactual exercises. In those exercises, we build artificial histories of economies in which some source of variation has been eliminated or modified in an illustrative manner. For example, we can evaluate how the economy would have behaved in the absence of changes in the volatility of the structural shocks or if the average monetary policy of one period had been applied in another. By interpreting those counterfactual histories, we attribute most of the defeat of the Great Inflation to monetary policy under Volcker and most of the Great Moderation after 1984 to good shocks. We incorporate information from those counterfactuals as we move along.

Our exercise in this section is closely related to the work of Christina and David Romer (1989; 2002a,b; 2004), except that we attack the problem from exactly the opposite perspective. While they let their narrative approach guide their empirical specification and like to keep a flexible relation with equilibrium models, we start from a tightly parameterized DSGE model of the U.S. economy and use the results of our estimation to read the narrative told by the documents. We see both strategies as complementary since each can teach us much of interest. Quite remarkably, given the 
different research designs, many of our conclusions are similar to the views expressed by Romer and Romer.

\subsection{The Martin Era: Resistance and Surrender}

William McChesney Martin, the Chairman of the Fed between April 2, 1951, and January 31, 1970, knew how to say no. On December 3, 1965, he dared to raise the discount rate for the first time in more than five years, despite warnings from the Treasury secretary, Henry Fowler, and the chairman of the Council of Economic Advisors, Gardner Ackley, that President Lyndon Johnson disapproved of such a move. Johnson, a man not used to seeing his orders ignored, was angered by Martin's unwelcome display of independence and summoned him to a meeting at his Texas ranch. There, for over an hour, he tried to corner the Chairman of the Fed with the infamous bullying tactics that had made him a master of the Senate in years past. Martin, however, held his ground and carried the day: The raise would stand. Robert Bremner starts his biography of Martin with this story. ${ }^{8}$ The choice is most appropriate. The history of this confrontation illustrates better than any other event our econometric results.

The early 1960s were the high years of Martin's tenure. The era of the "New Economics" combined robust economic growth, in excess of 5 percent, and low inflation, below 3 percent. According to our estimated model, this moderate inflation was, in part, a reflection of Martin's views about economic policy. Bremner (2004, p. 122) summarizes Martin's guiding principles this way: Stable prices were crucial for the correct working of a market economy and the Fed's main task was to maintain that stability. In Martin's own words, "the Fed has a responsibility to use the powers it possesses over economic events to dampen excesses in economic activity [by] keeping the

\footnotetext{
8 Bremner (2004, pp. 1-2). This was not the only clash of Martin with a president of the United States. In late 1952, Martin bumped into Harry Truman leaving the Waldorf Astoria Hotel in New York City. To Martin’s “Good afternoon,” Truman wryly replied, "Traitor!” Truman was deeply displeased by how the Fed had implemented the accord of March 3, 1951, between the Fed and the Treasury that ended the interest rate peg in place since 1942 (Bremner, 2004, p. 91).
}

use of credit in line with resources available for production of goods and services."9 Martin was also opposed to the idea (popular at the time) that the U.S. economy had a built-in bias toward inflation, a bias the Fed had to accommodate through monetary policy. Sumner Slichter, an influential professor of economics at Harvard, was perhaps the most vocal proponent of the built-in bias hypothesis. In Martin's own words, "I refuse to raise the flag of defeatism in the battle of inflation" and "there is no validity whatever in the idea that any inflation, once accepted, can be confined to moderate proportions." 10 As we will see in the next subsection, this opposition stands in stark contrast to Burns's pessimistic view of inflation, which had many points of contact with Slichter's.

Our estimates of $\gamma_{\Pi, t}$, above 1 and growing during the period, clearly tell us that Martin was doing precisely that: working to keep inflation low. Our result also agrees with Romer and Romer's (2002a) narrative and statistical evidence regarding the behavior of the Fed during the late 1950s. We must not forget, however, that our estimates in FGR suggest as well that the good performance of the economy from 1961 to 1965 was also the consequence of good positive shocks.

The stand against inflation started to be tested around 1966. Intellectually, more and more voices had been raised since the late 1950s defending the notion that an excessive concern with inflation was keeping the economy from working at full capacity. Bremner (2004, p. 138) cites Walter Heller and Paul Samuelson's statements before the Joint Economic Committee in February 1959 as examples of an attitude that would soon gain strength. The following year, Samuelson and Robert Solow's (1960) classic paper about the Phillips curve was taken by many as providing

\footnotetext{
9 Martin's testimony to the Joint Economic Committee, February 5, 1957 (cited by Bremner 2004, p. 123).

${ }^{10}$ The first quotation is from the New York Times, March 16, 1957, where Martin was expressing dismay for having reached a 2 percent rate of inflation. The second quotation is from the Wall Street Journal, August 19, 1957. Martin also thought that Keynes himself had changed his views on inflation after the war (they had talked privately on several occasions) and that, consequently, Keynesian economists were overemphasizing the benefits of inflation. See Bremner (2004, pp. 128 and 229).
} 
an apparently sound empirical justification for a much more sanguine position with respect to inflation: "In order to achieve the nonperfectionist's goal of high enough output to give us no more than 3 percent unemployment, the price index might have to rise by as much as 4 to 5 percent per year. That much price rise would seem to be the necessary cost of high employment and production in the years immediately ahead" (Samuelson and Solow, 1960, p. 192). ${ }^{11}$ Heller's and Tobin's arrival on the Council of Economic Advisors transformed the critics into the insiders.

The pressures on monetary policy were contained during Kennedy's administration, in good part because C. Douglas Dillon, the secretary of the Treasury and a Rockefeller Republican, sided on many occasions with Martin against Heller. ${ }^{12}$ But the changing composition of the Board of Governors and the arrival of Johnson, with his expansionary fiscal programs, the escalation of the Vietnam War, and the departure of Dillon from the Treasury Department, changed the weights of power.

While the effects of the expansion of federal spending in the second half of the 1960s often play a central role in the narrative of the start of the Great Inflation, the evolution of the Board of Governors has received less attention. Heller realized that, by carefully selecting the governors, he could shape monetary policy without the need to ease Martin out. This was an inspired observation, since up to that moment, the governors who served under the Chairman had played an extremely small role in monetary policy and the previous administrations had, consequently, shown little interest in their selection. The strat-

\footnotetext{
11 The message of the paper is, however, much more subtle than laying down a simple textbook Phillips curve. As Samuelson and Solow (1960) also say in the next page of their article (p. 193), "All of our discussion has been phrased in short-run terms, dealing with what might happen in the next few years. It would be wrong, though, to think that our Figure 2 menu that relates obtainable price and unemployment behavior will maintain its shape in the longer run. What we do in a policy way during the next few years might cause it to shift in a definite way."

12 In particular, Dillon's support for Martin's reappointment for a new term in 1963 was pivotal. Hetzel (2008, p. 69) suggests that President Kennedy often sided with Dillon and Martin over Heller to avoid a gold crisis on top of the problems with the Soviet Union over Cuba and Berlin.
}

egy worked. Heller's first choice, George W. Mitchell, would become a leader of those preferring a more expansionary monetary policy on the FOMC.

By 1964, Martin was considerably worried about inflation. He told Johnson: "I think we're heading toward an inflationary mess that we won't be able to pull ourselves out of." 13 In 1965, he ran into serious problems with the president, as discussed at the beginning of this section. The problems appeared again in 1966 with the appointment of Brimmer as a governor against Martin’s recommendation. During all this time, Martin stuck to his guns, trying to control inflation even if it meant erring on the side of overtightening the economy. Our estimated $\gamma_{\Pi, t}$ captures this attitude with an increase from around 1965 to around 1968.

But by the summer of 1968, Martin gave in to an easing of monetary policy after the tax surcharge was passed by Congress. As reported by Hetzel (2008), at the time, the FOMC was divided into two camps: members more concerned about inflation (such as Al Hayes, the president of the Federal Reserve Bank of New York) and members more concerned about output growth (Brimmer, ${ }^{14}$ Maisel, ${ }^{15}$ and Mitchell, all three appointees of Kennedy and Johnson). Martin, always a seeker of consensus, was growlingly incapable of carrying the day. ${ }^{16}$ Perhaps Martin felt that the political climate had moved away from a commitment

\footnotetext{
${ }^{13}$ Oral history interview with Martin, Lyndon B. Johnson Library (quoted by Bremner, 2004, p. 191).

${ }^{14}$ Brimmer is also the first African American to have served as a governor and was, for a while, a faculty member at the University of Pennsylvania.

${ }^{15}$ Sherman Maisel was a member of the Board of Governors between 1965 and 1972. Maisel, a professor at the Haas School of Business at the University of California-Berkeley, has the honor of being the first academic economist appointed as a governor after Adolph Miller, one of the original governors in 1914. As he explained in his book, Managing the Dollar (one of the first inside looks at the Fed and still a fascinating read today), Maisel was also a strong believer in the Phillips curve: "There is a trade-off between idle men and a more stable value of the dollar. A conscious decision must be made as to how much unemployment and loss of output is acceptable in order to get smaller price rises" (Maisel, 1973, p. 285). Maisel's academic and Keynesian background merged in his sponsoring of the MPS model mentioned in Section 2.

${ }^{16}$ On one occasion, Maisel felt strongly enough to call a press conference to explain his dissenting vote in favor of more expansion.
} 
to fight inflation. ${ }^{17}$ Or perhaps he was just exhausted after many years running the Fed (at the last meeting of the FOMC in which he participated, he expressed feelings of failure for not having controlled inflation). No matter what the exact reason was, monetary policy eased drastically in comparison with what was being called for by the Taylor rule with a $\gamma_{\Pi, t}$ above 1 . Thus, our estimated $\gamma_{\Pi, t}$ starts to plunge in the spring of 1968, reflecting that the increases in the federal funds rate passed at the end of 1968 and in 1969 were, according to our estimated Taylor rule, not aggressive enough given the state of the economy. The genie of the Great Inflation was out of the bottle.

\subsection{The Burns-Miller Era: Monetary Policy in the Time of Turbulence}

Arthur F. Burns started his term as Chairman of the Fed on February 1, 1970. A professor of economics at Columbia University and the president of the National Bureau of Economic Research between 1957 and 1967, Burns was the first academic economist to hold the chairmanship. All the previous nine Chairmen had been bankers or lawyers. However, any hope that his economics education would make him take an aggressive stand against the inflation brewing during the last years of Martin's tenure quickly disappeared. The federal funds rate fell from an average of 8.02 percent during 1970:Q1 to 4.12 percent by 1970:Q4. The justification for those reductions was the need to jump-start the economy, which was stacked in the middle of the first recession in nearly a decade, since December 1969. But since inflation stayed at 4.55 percent by the end of 1970, the reduction in the nominal rate meant that real interest rates sank into the negative region.

\footnotetext{
${ }^{17}$ Meltzer (2010, p. 549) points out that Martin and the other Board members might have been worried by Johnson's appointment, at the suggestion of Arthur Okun (the chairman of the Council of Economic Advisors at the time), of a task force to review changes in the Federal Reserve System. That message only became reinforced with the arrival of a new administration in 1969, given Richard Nixon's obsession with keeping unemployment as low as possible. (Nixon was convinced that he had lost the 1960 presidential election to a combination of vote fraud and tight monetary policy.)
}

Our smoothed estimate of $\gamma_{\Pi, t}$ in Figure 2 responds to this behavior of the Fed by quickly dropping during the same period. This indicates that the actual reduction in the federal funds rate was much more aggressive than the reduction suggested by the (important) fall in output growth and the (moderate) fall in inflation. Furthermore, the likelihood function accounts for the persistent fall in the real interest rate with a persistent fall in $\gamma_{\Pi, t}$.

Burns did little over the next few years to return $\gamma_{\Pi, t}$ to higher values. Even if the federal funds rate had started to grow by the end of 1971 (after the 90-day price controls announced on August 15 of that year as part of Nixon's New Economic Policy) and reached new highs in 1973 and 1974, it barely kept up with inflation. The real interest rate was not above our benchmark value of 2 percent until the second quarter of 1976. Later, in 1977, the federal funds rate was only raised cautiously, despite the evidence of strong output growth after the 1973-75 recession and that inflation remained relatively high.

Our econometric results come about because the Taylor rule does not care about the level of the interest rate in itself, but by how much inflation deviates from $\Pi$. If $\gamma_{\Pi, t}>1$, the increases in the federal funds rate are bigger than the increases in inflation. This is not what happened during Burns's tenure: The real interest rate was above the cutoff of 2 percent that we proposed before only in three quarters: his first two quarters as Chairman (1970:Q2 and 1970:Q3) and in 1976:Q2. This observation, by itself, should be sufficient proof of the stand of monetary policy during the period. ${ }^{18}$

Burns's successor, William Miller, did not have time to retract these policies in the brief interlude of his tenure, from March 8, 1978, to August 6, 1979. But he also did not have either the capability, since his only experience in the conduct of monetary policy was serving as a

\footnotetext{
${ }^{18}$ A memorandum prepared at the end of December 1997 by two of Carter's advisers reveals the climate of the time, proposing not to reappoint Chairman Burns for a third term because he was more concerned with inflation than unemployment (memo for the president on the role of the Federal Reserve, Box 16, R.K. Lipshitz Files, Carter Library, December 10, 1977, pp. 1-2; cited by Meltzer, 2010, p. 922).
} 
director of the Federal Reserve Bank of Boston, or the desire, since he had little faith in restrictive monetary policy's ability to lower inflation. ${ }^{19}$ Thus, our estimated $\gamma_{\Pi, t}$ remains low during that time. ${ }^{20}$

Burns was subject to strong pressure from Nixon. ${ }^{21}$ His margin of maneuver was also limited by the views among many leading economists that overestimated the costs of disinflation and who were in any case skeptical of monetary policy. $^{22}$ But his own convictions leaned in the same direction. According to the recollections of Stephen H. Axilrod, a senior staff member at the

${ }^{19}$ Miller stated, "Our attempts to restrain inflation by using conventional stabilization techniques have been less than satisfactory. Three years of high unemployment and underutilized capital stock have been costly in terms both of lost production and of the denial to many of the dignity that comes from holding a productive job. Yet, despite this period of substantial slack in the economy, we still have a serious inflation problem" (Board of Governors, 1978, p. 193; quoted by Romer and Romer, 2004, p. 140).

20 The situation with Miller reached the surrealistic point when, as narrated by Kettl (1986), Charles Schultze, the chairman of the Council of Economic Advisors, and Michael Blumenthal, the Treasury secretary, were leaking information to the press to pressure Miller to tighten monetary policy.

${ }^{21}$ Perhaps the clearest documented moment is the meeting between Nixon and Burns on October 23, 1969, right after Burns's nomination, as narrated by John Ehrlichman (1982, pp. 248-49): "I know there's the myth of the autonomous Fed...Nixon barked a quick laugh...and when you go up for confirmation some Senator may ask you about your friendship with the President. Appearances are going to be important, so you can call Ehrlichman to get messages to me, and he'll call you." The White House continued its pressure on Burns by many different methods, from constant conversations to leaks to the press (falsely) accusing Burns of requesting a large wage increase. These, and many other histories, are collected in a fascinating article by Abrams (2006).

22 Three examples. First, Franco Modigliani testified before the U.S. Congress on July 20, 1971: "[Y] ou have to recognize that prices are presently rising, and no measure we can take short of creating massive unemployment is going to make the rate of change of prices substantially below 4 percent." Second, Otto Eckstein, the builder of one of the large macroeconometric models at the time, the DRI U.S. model, argued that it was not the Fed's job to solve structural inflation. Third, James Tobin (1974): "For the rest of us, the tormenting difficulty is that the economy shows inflationary bias even when there is significant involuntary unemployment. The bias is in some sense a structural defect of the economy and society... Chronic and accelerating inflation is then a symptom of a deeper social disorder, of which involuntary unemployment is an alternative symptom. Political economists may differ about whether it is better to face the social conflicts squarely or to let inflation obscure them and muddle through. I can understand why anyone who prefers the first alternative would be working for structural reform, for a new social contract. I cannot understand why he would believe that the job can be done by monetary policy. Within limits, the Federal Reserve can shift from one symptom to the other. But it cannot cure the disease.” The examples are quoted by Hetzel (2008, pp. 86, 89, and 128).
Board back then, Burns did not believe any theory of the economy-whether Keynesian or monetarist—could account for the business cycle; he dismissed the relation between the stock of money and the price level; and he was unwilling or unable to make a persuasive case against inflation to the nation and to the FOMC. ${ }^{23}$

In addition, Burns had a sympathetic attitude toward price and wage controls. For instance, he testified to Congress on February 7, 1973:

[T] here is a need for legislation permitting some direct controls over wages and prices...The structure of our economy-in particular, the power of many corporations and trade unions to exact rewards that exceed what could be achieved under conditions of active competition-does expose us to upward pressure on costs and prices that may be cumulative and self-reinforcing (cited by Hetzel, 2008, p. 79).

He reiterated that view in a letter to the president on June 1, 1973, in which he proposed to reintroduce mandatory price controls for large firms. ${ }^{24}$ In his view, controls could break the costpush spiral of the economy and the inflationary pressures triggered by the social unrest of the late 1960s and be a more effective instrument than open market operations, which could be quite costly in terms of employment and financial disturbances. ${ }^{25}$ In fact, many members of the FOMC believed that the introduction of price and wage controls in different phases between 1971 and 1973 had not only eased the need for monetary tightening, but also positively suggested that monetary policy should not impose further restraint on the economy. ${ }^{26}$ More interestingly, if price and wage controls were an argument for loose monetary policy, their easing was also an argument for expansionary policy, or as Governor Charles Partee put it during the FOMC meeting of January 11, 1973, the lifting of controls "might necessitate a somewhat faster rate of monetary

\footnotetext{
${ }^{24}$ Burns papers, B_N1, June 1, 1973, as cited by Meltzer (2010, p. 787).

${ }^{25}$ At the time, many financial institutions were subject to ceiling rates on deposits, which could have made them bankrupt in the case of a fast tightening of monetary policy.

${ }^{26}$ Maisel's diary entry for August 25, 1971; cited by Meltzer, 2010, p. 790.
} 
growth to finance the desired growth in real output under conditions of greater cost-push inflation than would have prevailed with tighter controls" (cited by Meltzer, 2010, p. 815).

Burns's 1979 Per Jacobsson lecture is a revealing summary of Burns's own views on the origins and development of inflation. He blamed the growing demands of different social groups during the late 1960s and early 1970s and the federal government's willingness to concede to them as the real culprit behind inflation. Moreover, he felt that the Fed could not really stop the inflationary wave: If the Federal Reserve then sought to create a monetary environment that fell seriously short of accommodating the upward pressures on prices that were being released or reinforced by governmental action, severe difficulties could be quickly produced in the economy. Not only that, the Federal Reserve would be frustrating the will of Congress to which it was responsible.

But beyond Burns's own defeatist attitude toward inflation, he was a most unfortunate Chairman. He was in charge during a period of high turbulence and negative shocks, not only the 1973 oil shock, but also poor crops in the United States and the Soviet Union. Our model estimates large and volatile intertemporal shocks, $d_{t}$, and labor supply shocks, $\varphi_{t}$, during his tenure (see FGR for a plot of these shocks). Examples of intertemporal shocks include the final breakdown of the Bretton Woods Agreement, fiscal policy during the 197375 recession (with a temporary tax cut signed in March 1975 and increases in discretionary spending), and Nixon's price and wage controls (which most likely distorted intratemporal allocations). Examples of labor supply shocks include the historically high level of strikes in American industry during the early 1970s. (A major issue in the Republican primary of 1976 between Ford and Reagan was picketing rules for striking workers, a policy issue most unlikely to grab many voters' attention nowadays.)

Both types of shocks complicated monetary policy. Large positive intertemporal shocks increase aggregate demand. In our model, this translates partly into higher output and partly into higher inflation. Positive labor supply shocks increase wages, which pushes up the marginal cost and, therefore, inflation. Moreover, FGR show that, if volatility had stayed at historical levels, even with negative innovations, inflation would have been much lower and the big peak of 1973 avoided.

However, these negative shocks should not make us forget that, according to our model, if monetary policy had engineered higher real interest rates during those years, the history of inflation could have been different. In FGR we calculate that, had monetary policy behaved under Burns and Miller as it did under Volcker, inflation would have been 4.36 percent on average, instead of the observed 6.23 percent. The experience of Germany or Switzerland, which had much lower inflation than the United States during the same time, suggests that this was possible. After all, the peak of inflation in Germany was in 1971, well before any of the oil shocks. And in neither of these two European countries do we observe statements such as that by Governor Sheehan on the January 22, 1974, FOMC meeting: "[T]he Committee had no choice but to validate the rise in prices if it wished to avoid compounding the recession" (Hetzel, 2008, p. 93).

Thus, our reading of monetary policy during the Burns years through the lens of our model emphasizes the confluence of two phenomena: an accommodating position with respect to inflation and large and volatile shocks that complicated the implementation of policy. There is ample evidence in the historical record to support this view. This was, indeed, monetary policy in the time of turbulence.

\subsection{The Volcker Era: High Noon}

In his 1979 Per Jacobsson lecture cited earlier, Burns had concluded: "It is illusory to expect central banks to put an end to the inflation that now afflicts the industrial democracies." Paul Volcker begged to differ. He had been president of the Federal Reserve Bank of New York since August 1975 and, from that position, a vocal foe of inflation. In particular, during his years as a member of the FOMC, Volcker expressed concern that the Fed was consistently underpredicting 
inflation and that, therefore, monetary policy was more expansionary than conventionally understood (Meltzer, 2010, p. 942). ${ }^{27}$

In the summer of 1979, Jimmy Carter moved Miller to the Treasury Department. Then, he offered Volcker the chairmanship of the Board of Governors. Volcker did not hesitate to take it, but not before warning the president "of the need for tighter money-tighter than Bill Miller had wanted" (Volcker and Gyothen, 1992, p. 164) and the Senate in his confirmation hearings that "the only sound foundation for the continuing growth and prosperity of the American economy is much greater price stability" (U.S. Senate, 1979, p. 16; quoted by Romer and Romer, 2004, p. 156). Deep changes were coming and the main decisionmakers were aware of them.

We should be careful not to attribute all of the sharp break in monetary policy to Volcker's appointment. In 1975, the House passed Concurrent Resolution 133, the brainchild of Karl Brunner (Weintraub, 1977). This resolution, which asked the Fed to report to the House Banking Committee on objectives and plans with respect to the ranges of growth or diminution of monetary and credit aggregates in the upcoming twelve months, was a first victory for monetarism. Although the resolution probably did little by itself, it was a sign that times were changing. Congress acted again with the Full Employment and Balanced Growth Act of 1978, which required the Fed to report monetary aggregates in its reports to Congress. In April 1978, the federal funds rate started growing quickly, from a monthly average of 6.9 percent to 10 percent by the end of the year. This reflected a growing consensus on the FOMC (still with many dissenting voices) regarding the need for lower inflation. Figure 2 shows the start of an increase in $\gamma_{\Pi, t}$ around that time. At the same time, the new procedures for monetary policy that targeted money growth rates and reserves instead of the federal funds rate were not announced

\footnotetext{
27 This position links to an important point made by Orphanides (2002): Monetary policy decisions are implemented using realtime data, a point that our model blissfully ignores. In turbulent times such as the 1970s, this makes steering the ship of policy targets exceedingly difficult.
}

until October 6, 1979. Additionally, Goodfriend and King (2005) have argued that Volcker required some time before asserting his control over the FOMC. For instance, in the Board meeting of September 18, 1979, Volcker did obtain a rise in the discount rate, but only with three dissenting votes. As we argued in Section 2, all of these observations suggest that modeling the evolution of monetary policy as a smooth change may be more appropriate than assuming a pure break.

Regardless of the exact timing of changes in monetary policy, the evidence in Figure 2 is overwhelming: On or about August 1979, the character of monetary policy changed. The federal funds rate jumped to new levels, with the first significant long-lasting increase in the real interest rate in many years. Real interest rates would remain high for the remainder of the decade of the 1980s, partly reflecting high federal fund rates and partly reflecting the deeply rooted expectations of inflation among the agents. In any case, the response of monetary policy to inflation, $\gamma_{\Pi, t}$, was consistently high during the whole of Volcker's years.

An important question is the extent to which the formalism of the Taylor rule can capture the way in which monetary policy was conducted at the time, when money growth targeting and reserve management were explicitly tried (what Volcker called "practical monetarism"). We are not overly concerned about this aspect of the data because, in our DSGE model, there is a mapping between money targeting and the Taylor rule (Woodford, 2003). Thus, as long as we are careful to interpret the monetary policy shocks during the period (which we estimate were, indeed, larger than in other parts of the sample), our exercise should be relatively robust to this consideration. ${ }^{28}$ A much more challenging task could be to build a DSGE model with a richer set of monetary pol-

\footnotetext{
${ }^{28}$ This begets the question of why Volcker spent so much effort on switching the operating procedure of the Fed between 1979 and 1982. Volcker himself ventures that it was easier to sell a restrictive monetary policy in terms of money growth rates than in terms of interest rates: "More focus on the money supply also would be a way of telling the public that we meant business. People don't need an advanced course in economics to understand that inflation has something to do with too much money" (Volcker and Gyohten, 1992, pp. 167-68).
} 
icy rules and switches between them. However, at the moment, this goal seems infeasible. ${ }^{29}$

The impressions of participants in the monetary policy process reinforced the message of Figure 2. For instance, Axilrod (2009, p. 91) states:

During Paul Volcker's eight-year tenure as chairman of the Fed...policy changed dramatically. He was responsible for a major transformation—akin to a paradigm shift—-that was intended to greatly reduce inflation, keep it under control, and thereby restore the Fed's badly damaged reputation. Furthermore, it was almost solely because of Volcker that this particular innovation was put in place-one of the few instances in my opinion where a dramatic shift in policy approach could be attributed to a particular person's presence rather than mainly or just to circumstances.

Volcker himself was very explicit about his views $^{30}$ :

[M]y basic philosophy is over time we have no choice but to deal with the inflationary situations because over time inflation and unemployment go together...Isn't that the lesson of the 1970s? We sat around [for] years thinking we could play off a choice between one or the other...It had some reality when everybody thought processes were going to be stable...So in a very fundamental sense, I don't think we have the choice.

In fact, Volcker's views put him in the rather unusual position of being outvoted on February 24, 1986. In that meeting, a majority of four members of the Board voted against Volcker and two other dissenting members to lower the discount rate 50 basis points.

At the same time, and according to our model, Volcker was also an unlucky Chairman. The economy still suffered from large and negative shocks during his tenure, since the level and volatility

\footnotetext{
${ }^{29}$ The impact of the credit controls imposed by the Carter administration starting on March 14, 1980, is more difficult to gauge. Interestingly, we estimate a large negative innovation to the intratemporal preference shifter at that point in time, a likely reflection of the distortions of the controls in the intertemporal choices of households (see the historical description in Shreft, 1990).

${ }^{30}$ Volcker papers, Federal Reserve Bank of New York, speech at the National Press Club, Box 97657, January 2, 1980; quoted by Meltzer, 2010, p. 1034.
}

of the intratemporal preference shifter did not fall until later in his term. In FGR, we build a counterfactual in which Volcker is faced with the same structural shocks he faced in real life, but with the historical average volatility. In this counterfactual history, inflation falls to negative values by the end of 1983, instead of still hovering around 3 to 4 percent. It was a tough policy in a difficult time. However, despite these misfortunes and heavy inheritance from the past, our model tells us that monetary policy conquered the Great Inflation. The Great Moderation would have to wait for better shocks.

We started this subsection with Burns's own words in the 1979 Per Jacobsson lecture. In 1989, Volcker was invited to give the same lecture. What a difference a decade can make! While Burns was sad and pessimistic (his lecture was entitled "The Anguish of Central Banking”), Volcker was happy and confident (his lecture was entitled “The Triumph of Central Banking?"). Inflation had been defeated and he warned that "our collective experience strongly emphasizes the importance of dealing with inflation at an early stage" (Volcker, 1990, p. 14).

\subsection{The Greenspan Era: Speaking Like a Hawk and Walking Like a Dove}

These are the colorful words with which Laurence Meyer (2004, p. 83) summarizes Greenspan's behavior during Meyer's time as a governor (June 1996 to January 2002). Once and again,

[Greenspan] seemed to fall into a pattern: The Chairman would ask for no change in the funds rate, suggest that the time was approaching for action, and indicate that there was a high probability of a move at the next meeting. Then at the next meeting, he would explain that the data did not yet provide a credible basis for tightening, and in any case, that the markets didn't expect a move. However, he would conclude that he expected the Committee would be forced to move at the next meeting.

Meyer means these words in a positive way. In his opinion, Greenspan discovered before he did 
that the economy was being hit during the second half of the 1990s by an unusual sequence of positive shocks and directed monetary policy to take advantage of them.

We quote Meyer because it illustrates that Greenspan showed from the start that he knew how to respond to changing circumstances. He was appointed on August 11, 1987. In his confirmation hearings, he clearly reaffirmed the need to fight inflation. ${ }^{31}$ But after just a couple of months, on October 19, 1987, he reacted to the big crash of the stock market by declaring the Fed's disposition to serve as a source of liquidity, even if, in the short run, this could complicate the control of inflation.

Later, in early 1989, the federal funds rate started to fall, despite the fact that inflation remained at around 6 percent until the end of 1990. As shown in Figure 2, our estimate of $\gamma_{\Pi, t}$ picks up this fall by dropping itself. Moreover, it dropped fast. We estimate that $\gamma_{\Pi, t}$ was soon below 1 , back to the levels of Burns-Miller (although, for a while, there is quite a bit of uncertainty in our estimate). The parameter stayed there for the rest of Greenspan's tenure. The reason for this estimated low level of $\gamma_{\Pi, t}$ is that the real interest rate also started to fall rather quickly. At the same time, a remarkable sequence of good shocks delivered rapid output growth and low inflation.

In fact, in FGR we find that all of the shocks went right for monetary policy during the 1990s. A large string of positive and stable investmentspecific technological shocks delivered fast productivity growth, a falling intertemporal shifter lowered demand pressures, and labor supply shocks pressured wages downward-and, with them, marginal costs. This fantastic concatenation of shocks accounted for the bulk of the Great Moderation. In FGR, we calculate that without changes in volatility, the Great Moderation would have been much smaller. The SD of inflation

\footnotetext{
${ }^{31}$ Greenspan stated in his confirmation hearings: "[W]e allowed our system to take on inflationary biases which threw us into such a structural imbalance that, in order to preserve the integrity of the system, the Federal Reserve had to do what it did. Had it not acted in the way which it did at that time, the consequences would have been far worse than what subsequently happened" (U.S. Senate, 1987, p. 35; quoted by Romer and Romer, 2004, p. 158).
}

would have fallen by only 13 percent (instead of 60 percent in the data), the SD of output growth would have fallen by 16 percent (instead of 46 percent in the data), and the SD of the federal funds rate would have fallen by 35 percent (instead of 39 percent in the data). That is, the moderation in inflation fluctuations would have been only one-fifth as large as in the data (and the counterfactual mean would have actually been higher than in the data) and the moderation for output growth's SD only one-third.

We can push the argument even further. In FGR we build the counterfactual in which the average $\gamma_{\Pi, t}$ during the Greenspan years is plugged into the model at the time of Burns's appointment. Then, we keep $\gamma_{\Pi, t}$ at that level and hit the model with exactly the same shocks that we backed out from our estimation. This exercise is logically coherent, since we are working with a DSGE model and, therefore, the structural and volatility shocks are invariant to this class of interventions. We compute that the average monetary policy during Greenspan's years would not have made much of a difference in the 1970s. If anything, inflation would have been even slightly higher (6.83 percent in the counterfactual instead of 6.23 percent in the data). This finding contrasts with our counterfactual in which Volcker is moved to the Burns-Miller era. In this counterfactual, inflation would have been only 4.36 percent. To summarize, our reading of monetary policy during the Greenspan years is that it was not too different from the policy in the Burns-Miller era; it just faced much better shocks.

Is this result credible? First, it is clear that it is not a pure artifact of our model. A similar result is found in Sims and Zha (2006). These authors, using structural vector autoregressions with Markov switching, which imposes many fewer cross-equation restrictions than our analysis, do not find much evidence of differences in monetary policy across time (actually, Sims and Zha's position is even stronger than ours, since they do find that monetary policy was different even under Volcker). Second, there are hints in the data that lead us to believe that the results make sense. At the start of the 1994 inflation scare, 
when there were no signs of the "new economy" anywhere to be seen, Greenspan argued ${ }^{32}$ :

You know, I rarely feel strongly about an issue, and I very rarely sort of press this Committee. But let me tell you something about what's gnawing at me here. I am very sympathetic with the view that we've got to move and that we're going to have an extended period of moves, assuming the changes that are going on now continue in the direction of strength. It is very unlikely that the recent rate of economic growth will not simmer down largely because some developments involved in this particular period are clearly one-shot factors-namely, the very dramatic increase in residential construction and the big increase in motor vehicle sales. Essentially the two of those have added one-shot elements to growth. In the context of a saving rate that is not high, the probability is in the direction of this expansion slowing from its recent pace, which at the moment is well over 4 percent and, adjusting for weather effects, may be running over 5 percent. This is not sustainable growth, and it has nothing to do with monetary policy. In other words, it will come down. And the way a 3 percent growth feels, if I may put it that way, is a lot different from the way the expansion feels now.

I would be very concerned if this Committee went 50 basis points now because I don't think the markets expect it...I've been in the economic forecasting business since 1948, and I've been on Wall Street since 1948, and I am telling you I have a pain in the pit of my stomach, which in the past I've been very successful in alluding to. I am telling you —and I've seen these markets-this is not the time to do this. I think there will be a time; and if the staff's forecast is right, we can get to 150 basis points pretty easily. We can do it with a couple of $1 / 2$ point jumps later when the markets are in the position to know what we're doing and there's continuity. I really request that we not do this. I do request that we be willing to move again fairly soon, and maybe in larger increments; that depends on how things are evolving.

We construe this statement as revealing a low $\gamma_{\Pi t}$. We could present similar evidence regarding

${ }^{32}$ Board of Governors FOMC Transcripts, February 3-4, 1994, p. 55. the behavior of policy in the aftermath of the Long Term Capital Management fiasco or in the exit from the 2001 recession. But we feel the point has been made. We believe that our estimates are right: Monetary policy in the Greenspan years was similar to monetary policy under Burns and Miller. Instead, time-varying structural shocks were the mechanism that played a key role in the Great Moderation and the low inflation of 1987-2007.

\section{WHAT ARE WE MISSING?}

What is our model missing that is really important? The answer will tell us much about where we want to go in terms of research and where we need to be careful in our reading of monetary history. Of all the potential problems of our specification, we are particularly concerned about the following.

First, households and firms in the model observe the changes in the coefficients $\gamma_{\Pi t}$ and $\gamma_{y t}$ when they occur. A more plausible scenario would involve filtering in real time by the agents who need to learn the stand of the monetary authority from observed decisions. ${ }^{33}$ A similar argument can be made for the values of the SDs of all the other shocks in the economy. Unfortunately, introducing learning suffers from two practical difficulties: It is not obvious what is the best way to model learning about monetary policy, especially in a nonlinear environment such as ours where least-square rules may not work properly. And it would make the computation of the model nearly infeasible.

Second, we assume that monetary policy changes are independent of the events in the economy. However, many channels make this assumption untenable. For instance, each administration searches for governors of the Board who conform with its views on the economy (after all,

\footnotetext{
${ }^{33}$ The difficulties in observing monetary policy changes can be illustrated by Axilrod's description of a lunch with Arthur Burns shortly after the announcement of Volcker's new policy. According to Axilrod (2009, p. 100), Burns stated: "You are not really going to be doing anything different from what we were doing. If an insider like Burns had difficulties in filtering Volcker's behavior, it is hard to conclude anything but that the average agents in the economy had difficulties as well."
} 
this is what a democracy is supposed to be about). We saw how Heller discovered that an administration could select governors to twist the FOMC toward its policy priorities. This is a tradition that has continued. Meyer (2004, p. 17) describes the process for his own appointment as one clearly guided by the desire of the Clinton administration to make monetary policy more accommodative and growth-oriented. As long as the party in power is a function of the state of the economy, the composition of the FOMC will clearly be endogenous. Similarly, changes in public perception of the dangers of inflation certainly weighed heavily on Carter when he appointed Volcker to lead the Fed in 1979.

Third, and related to our two previous points, evolving beliefs about monetary policy might be endogenous to the developments of events and lead to self-confirming equilibria. This is a point emphasized by Cho, Williams, and Sargent (2002) and Sargent (2008).

Fourth, our technological drifts are constant over time. The literature on long-run risk has highlighted the importance of slow-moving components in growth trends (Bansal and Yaron, 2004). It may be relevant to judge monetary policy to estimate a model in which we have these slow-moving components, since the productivity slowdown of the 1970s and the productivity acceleration of the late 1990s are bound to be reflected in our assessment of the stance of monetary policy during those years. This links us back to some of the concerns expressed by Orphanides (2002). At the same time and nearly by definition, there is very little information in the data about this component.

Fifth, our model is a closed economy. However, the considerations regarding exchange rates have often played an important role in monetary policymaking. For instance, during the late 1960s, the United States fought an increasingly desperate battle to keep the Bretton Woods Agreement alive, which included the Fed administering a program to voluntarily reduce the amount of funds that American banks could lend abroad (Meltzer, 2010, p. 695) and purchasing long-term Treasury bonds to help the British pound stabilize after its 1967 devaluation. The end of Bretton Woods also deeply influenced policymakers in the early 1970s. Later, Volcker's last years at the Fed were colored by the Plaza and Louvre Accords and the attempts to manage the exchange rate between the U.S. dollar and the Japanese yen.

Finally, our model ignores fiscal policy. The experience of the 1960s, in which there was an explicit attempt at coordinating fiscal and monetary policies, and the changes in long-run interest rates possibly triggered by the fiscal consolidations of the 1990s indicate that the interaction between fiscal and monetary policies deserves much more attention, a point repeatedly made by Chris Sims (for example in Sims, 2009).

\section{CONCLUDING REMARKS}

The title of this paper is not only a tribute to Friedman and Schwartz's (1971) opus magnum, but also a statement of the limitations of our investigation. Neither the space allocated to us ${ }^{34}$ nor our own abilities allow us to get even close to Friedman and Schwartz's achievements. We have tried to demonstrate, only, that the use of modern equilibrium theory and econometric methods allows us to read the monetary policy history of the United States since 1959 in ways that we find fruitful. We proposed and estimated a DSGE model with stochastic volatility and parameter drifting. The model gave us a clear punch line: First, there is ample evidence of both strong changes in the volatility of the structural shocks that hit the economy and changes in monetary policy. The changes in volatility accounted for most of the Great Moderation. The changes in monetary policy mattered for the rise and conquest of the Great Inflation. Inflation stayed low during the next decades in large part due to good shocks. When we go to the historical record and use the results of our estimation to read and assess the documentary evidence, we find ample confirmation, in our opinion, that the model, despite all its limitations, is teaching us important lessons.

\footnotetext{
${ }^{34}$ For an only slightly longer period than ours, Meltzer (2010) requires 1,300 pages to cover the details of the history of monetary policy in the United States, including the evolution of operational procedures that we have not even mentioned.
} 
As we argued in the previous section, we leave much unsaid. Hopefully, the results in this paper will be enticing enough for other researchers to continue a close exploration of recent monetary policy history with the tools of modern dynamic macroeconomics.

\section{REFERENCES}

Abrams, Burton A. "How Richard Nixon Pressured Arthur Burns: Evidence from the Nixon Tapes." Journal of Economic Perspectives, Fall 2006, 20(4), pp. 177-88.

Aruoba, S. Boragan and Schorfheide, Frank. "Sticky Prices versus Monetary Frictions: An Estimation of Policy Trade-offs.” American Economic Journal: Macroeconomics (forthcoming).

Aruoba, S. Boragan; Fernández-Villaverde, Jesus and Rubio-Ramírez, Juan F. "Comparing Solution Methods for Dynamic Equilibrium Economies.” Journal of Economic Dynamics and Control, December 2006, 30(12), pp. 2477-508.

Axilrod, Stephen H. Inside the Fed: Monetary Policy and Its Management, Martin through Greenspan to Bernanke. Cambridge, MA: MIT Press, 2009.

Bansal, Ravi and Yaron, Amir. "Risks for the Long Run: A Potential Resolution of Asset Pricing Puzzles." Journal of Finance, August 2004, 59(4), pp. 1481-509.

Board of Governors of the Federal Reserve System. "Statement by G. William Miller, Chairman, Board of Governors of the Federal Reserve System, before the Committee on the Budget, U.S. Senate, March 15, 1978," in Federal Reserve Bulletin, March 1978, 64(3), pp. 190-94. http://fraser.stlouisfed.org/publications/frb/1978/download/60182/frb 031978.pdf.

Board of Governors of the Federal Reserve System. Meeting of the Federal Open Market Committee, February 3-4, 1994 (FOMC Transcripts); www.federalreserve.gov/monetarypolicy/files/FOMC19940204meeting.pdf.

Brayton, Flint; Levin, Andrew; Lyon, Ralph and Williams John C. "The Evolution of Macro Models at the Federal Reserve Board.” Carnegie-Rochester Conference Series on Public Policy, December 1997, 47(1), pp. 43-81.

Bremner, Robert P. Chairman of the Fed: William McChesney Martin Jr. and the Creation of the American Financial System. New Haven, CT: Yale University Press, 2004.

Burns, Arthur F. “The Anguish of Central Banking.” The 1979 Per Jacobsson Lecture, Belgrade, Yugoslavia, September 30, 1979; www.perjacobsson.org/lectures/1979.pdf.

Christiano, Lawrence; Eichenbaum, Martin and Evans, Charles L. "Nominal Rigidities and the Dynamic Effects of a Shock to Monetary Policy.” Journal of Political Economy, June 2005, 113(1), pp. 1-45.

Cho, In-Koo; Williams, Noah and Sargent, Thomas J. "Escaping Nash Inflation.” Review of Economic Studies, January 2002, 69(1), pp. 1-40.

Clarida, Richard; Galí, Jordi and Gertler, Mark. "Monetary Policy Rules and Macroeconomic Stability: Evidence and Some Theory.” Quarterly Journal of Economics, February 2000, 115(1), pp. 147-80.

Cogley, Timothy and Sargent, Thomas J. "Evolving Post-World War II U.S. Inflation Dynamics,” in Ben S. Bernanke and Kenneth Rogoff, eds., NBER Macroeconomics Annual 2001. Volume 16. Cambridge, MA: MIT Press, 2002, pp. 331-88. 


\section{Fernández-Villaverde, Guerrón-Quintana, Rubio-Ramírez}

Cogley, Timothy and Sargent, Thomas J. "Drifts and Volatilities: Monetary Policies and Outcomes in the Post WWII U.S.” Review of Economic Dynamics, April 2005, 8(2), pp. 262-302.

Dotsey, Michael; King, Robert G. and Wolman, Alexander L. "State-Dependent Pricing and the General Equilibrium Dynamics of Money and Output.” Quarterly Journal of Economics, May 1999, 114(2), pp. 655-90.

Ehrlichman, John. Witness to Power: The Nixon Years. New York: Simon and Schuster, 1982.

Fernández-Villaverde, Jesús and Rubio-Ramírez, Juan F. "Estimating Macroeconomic Models: A Likelihood Approach.” Review of Economic Studies, October 2007, 74(4), pp. 1059-87.

Fernández-Villaverde, Jesús and Rubio-Ramírez, Juan F. "How Structural Are Structural Parameters?” in Daron Acemoglu; Kenneth Rogoff and Michael Woodford, eds., NBER Macroeconomics Annual 2007. Volume 22. Chicago: University of Chicago Press, 2008, pp. 83-137.

Fernández-Villaverde, Jesús; Guerrón-Quintana, Pablo and Rubio-Ramírez, Juan F. "Fortune or Virtue: TimeVariant Volatilities Versus Parameter Drifting in U.S. Data.” NBER Working Paper No. 15928, National Bureau of Economic Research, April 2010; www.nber.org/papers/w15928.

Fisher, Jonas. "The Dynamic Effects of Neutral and Investment-Specific Technology Shocks.” Journal of Political Economy, June 2006, 114(3), pp. 413-52.

Friedman, Milton and Schwartz, Anna J. A Monetary History of the United States, 1867-1960. Princeton, NJ: Princeton University Press, 1971.

Goodfriend, M. and King, Robert. "The Incredible Volcker Disinflation.” Journal of Monetary Economics, July 2005, 52(5), pp. 981-1015.

Greenwood, Jeremy; Herkowitz, Zvi and Krusell, Per. "Long-Run Implications of Investment-Specific Technological Change.” American Economic Review, June 1997, 87(3), pp. 342-62.

Hall, Robert E. "Macroeconomic Fluctuations and the Allocation of Time." Journal of Labor Economics, January 1997, 15(1 Part 1), pp. S223-S250.

Hetzel, Robert L. The Monetary Policy of the Federal Reserve: A History. New York: Cambridge University Press, 2008.

Hurwicz, Leonid. "On the Structural Form of Interdependent Systems," in Ernest Nagel, Patrick Suppes, and Alfred Tarski, eds., Logic, Methodology and Philosophy of Science: Proceedings of the 1960 International Congress. Stanford, CA: Stanford University Press, 1962, pp. 232-39.

Jaimovich, Nir and Siu, Henry E. "The Young, the Old, and the Restless: Demographics and Business Cycle Volatility.” American Economic Review, June 2009, 99(3), pp. 804-26.

Judd, Kenneth L. Numerical Methods in Economics. Cambridge, MA: MIT Press, 1998.

Justiniano, Alejandro and Primiceri, Giorgio. "The Time Varying Volatility of Macroeconomic Fluctuations." American Economic Review, June 2008, 98(3), pp. 604-41.

Kettl, Donald. Leadership at the Fed. New Haven, CT: Yale University Press, 1986.

Kim, Chang-Jin and Nelson, Charles R. "Has the U.S. Economy Become More Stable? A Bayesian Approach Based on a Markov-Switching Model of the Business Cycle." Review of Economics and Statistics, November 1998, 81(4), pp. 608-16.

Kiyotaki, Nobuhiro and Wright, Randall. "On Money as a Medium of Exchange.” Journal of Political Economy, August 1989, 97(4), pp. 927-54.

Lagos, Ricardo and Wright, Randall. "A Unified Framework for Monetary Theory and Monetary Analysis." Journal of Political Economy, June 2005, 113(3), pp. 463-84. 
Lubick, Thomas A. and Schorfheide, Frank. "Testing for Indeterminacy: An Application to U.S. Monetary Policy." American Economic Review, March 2004, 94(1), pp. 190-217.

Maisel, J. Sherman. Managing the Dollar. New York: W.W. Norton, 1973.

McConnell, Margaret M. and Pérez-Quirós, Gabriel. "Output Fluctuations in the United States: What Has Changed Since the Early 1980's?” American Economic Review, December 2000, 90(5), pp. 1464-76.

Meltzer, Allan H. A History of the Federal Reserve. Volume 2, Books 1 and 2. Chicago: University of Chicago Press, 2010.

Meyer, Laurence H. A Term at the Fed: An Insider’s View. New York: Harper Collins, 2004.

Orphanides, Athanasios. "Monetary Policy Rules and the Great Inflation.” American Economic Review, May 2002, 92(2), pp. 115-20.

Romer, Christina D. and Romer, David H. "Does Monetary Policy Matter? A New Test in the Spirit of Friedman and Schwartz,” in Olivier J. Blanchard and Stanley Fischer, eds., NBER Macroeconomics Annual 1989. Volume 4. Cambridge, MA: MIT Press, 1989, pp. 121-70.

Romer, Christina D. and Romer, David H. "A Rehabilitation of Monetary Policy in the 1950's." American Economic Review, May 2002a, 92(2), pp. 121-27.

Romer, Christina D. and Romer, David H. "The Evolution of Economic Understanding and Postwar Stabilization Policy." Presented at a symposium sponsored by the Federal Reserve Bank of Kansas City, "Rethinking Stabilization Policy,” Jackson Hole, Wyoming, August 29-31, 2002b, pp. 11-78; www.kc.frb.org/PUBLICAT/SYMPOS/2002/pdf/S02RomerandRomer.pdf.

Romer, Christina D. and Romer, David. "Choosing the Federal Reserve Chair: Lessons from History." Journal of Economic Perspectives, Winter 2004, 18(1), pp. 129-62.

Samuelson, Paul A. and Solow, Robert M. "Analytical Aspects of Anti-Inflation Policy.” American Economic Review, May 1960, 50(2), pp. 177-94.

Sargent, Thomas J. "Evolution and Intelligent Design.” American Economic Review, March 2008, 98(1), pp. 5-37.

Schmitt-Grohé, Stephanie and Uribe, Martín. "Optimal Fiscal and Monetary Policy in a Medium-Scale Macroeconomic Model," in Mark Gertler and Kenneth Rogoff, eds., NBER Macroeconomics Annual 2005, Cambridge, MA: MIT Press, 2006, pp. 382-425; www.nber.org/books/gert06-1.

Schreft, Stacey L. "Credit Controls: 1980.” Federal Reserve Bank of Richmond, Economic Review, November/ December 1990, 6, pp. 25-55; www.richmondfed.org/publications/research/economic review/1990/pdf/er760603.pdf.

Sims, Christopher A. "Price Level Determination in General Equilibrium." Plenary talk at the Society for Economic Dynamics Annual Meeting, July 2-4, 2009, Istanbul, Turkey.

Sims, Christopher A. and Zha, Tao. "Were There Regime Switches in U.S. Monetary Policy?” American Economic Review, March 2006, 96(1), pp. 54-81.

Smets, Frank R. and Wouters, Raf. "An Estimated Dynamic Stochastic General Equilibrium Model of the Euro Area.” Journal of the European Economic Association, September 2003, 1(5), pp. 1123-75.

Stock, James H. and Watson, Mark W. "Has the Business Cycle Changed, and Why?" in Mark Gertler and Kenneth Rogoff, eds., NBER Macroeconomics Annual 2002. Volume 17. Cambridge, MA: MIT Press, 2003, pp. 159-218.

Stock, James H. and Watson, Mark W. "Why Has U.S. Inflation Become Harder to Forecast?” Journal of Money, Credit, and Banking, February 2007, 39(S1), pp. 3-33. 


\section{Fernández-Villaverde, Guerrón-Quintana, Rubio-Ramírez}

Tobin, James. "Monetary Policy in 1974 and Beyond.” Brookings Papers on Economic Activity, 1974, 1, pp. 219-32.

U.S. Senate. Committee on Banking, Housing, and Urban Affairs. "Nomination of Paul A. Volcker." Washington, DC: U.S. Government Printing Office, 1979.

U.S. Senate. Committee on Banking, Housing, and Urban Affairs. "Nomination of Alan Greenspan." Washington, DC: U.S. Government Printing Office, 1987.

Volcker, Paul A. "The Triumph of Central Banking?” The 1990 Per Jacobbson Lecture, Washington, DC, September 23, 1990; www.perjacobsson.org/lectures/1990.pdf.

Volcker, Paul A. and Gyohten, Toyoo. Changing Fortunes: The World's Money and the Threat to American Leadership. New York: Times Books/Random House, 1992.

Wallace, Neil. "Whither Monetary Economics?” International Economic Review, November 2001, 42(4), pp. 847-69.

Weintraub, Robert. "Monetary Policy and Karl Brunner." Journal of Money, Credit, and Banking, February 1977, 9(1 Part 2), pp. 255-58.

Woodford, Michael. Interest and Prices: Foundations of a Theory of Monetary Policy. Princeton, NJ: Princeton University Press, 2003. 